Historic, Archive Document

Do not assume content reflects current scientific knowledge, policies, or practic 


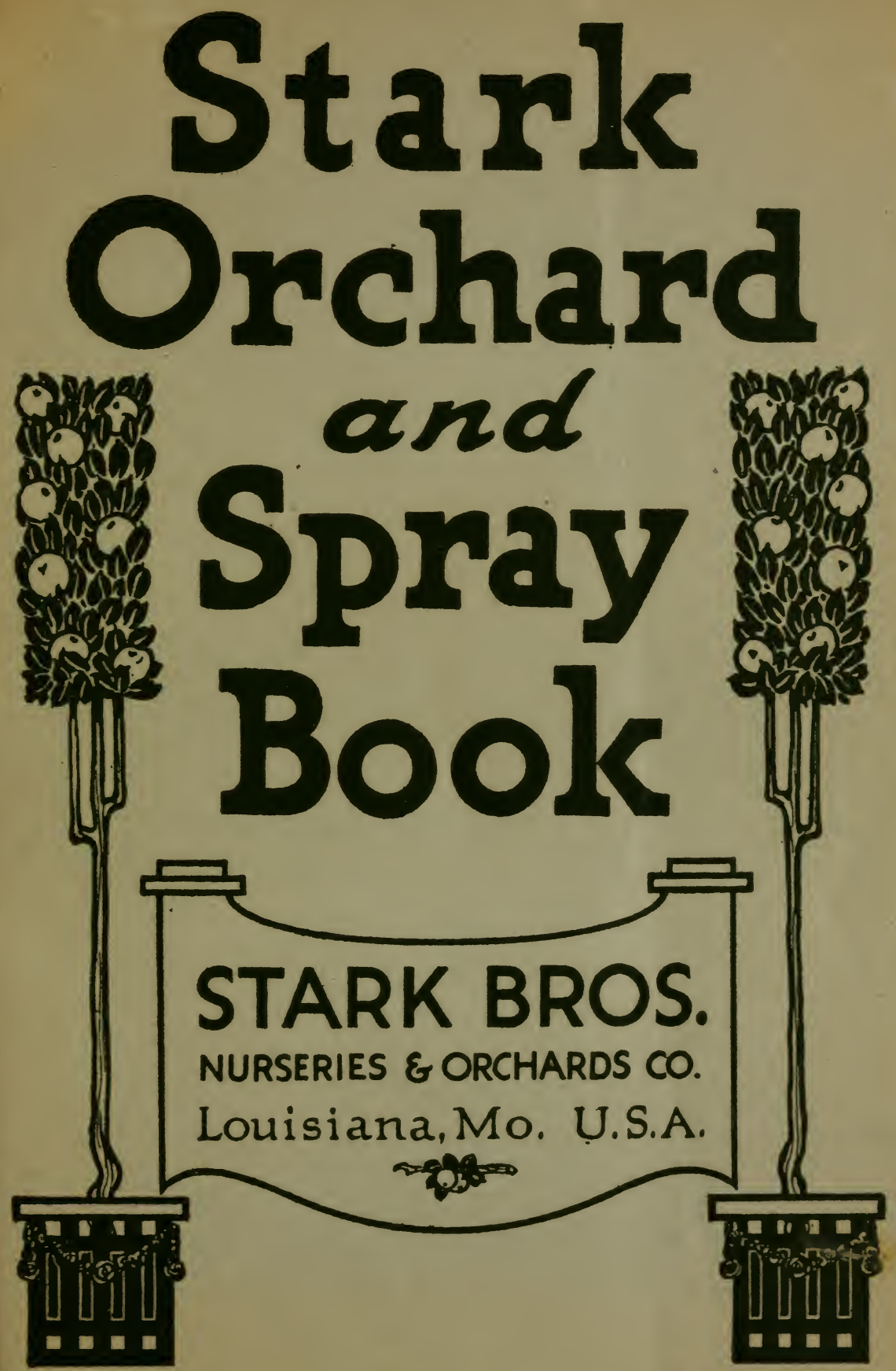



\section{Stark Orchard and Spray Book}

COPYRIGHT 1913

BY STARK BROS. N. \& O. CO.

$\mathrm{Published} \mathbf{B y}$

Stark Bros. Nurseries \& Orchards Co. I.OUISIANA, MO., U. S. A. 


\section{Contents}

\section{BOOK I.}

Planting and Growing Orchards 5 When to Plant............... 5 Age of Trees............... 5

Orchard Lands............... 7

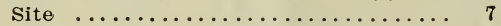

Soils $\ldots \ldots \ldots \ldots \ldots \ldots \ldots \ldots \ldots \ldots \ldots$

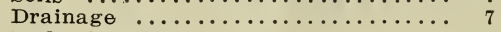

Arrival of Trees.............. 7

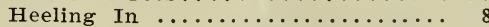

Planting

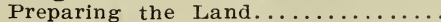

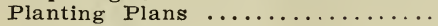

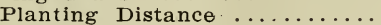

Pollination $\ldots \ldots \ldots \ldots \ldots \ldots \ldots \ldots . \ldots 10$

Fillers ................... 10

Intercropping $\ldots \ldots \ldots \ldots \ldots \ldots \ldots \ldots$ 11

Laying Out the Orchard........... 11

Digging Holes ............... 12

Distributing Trees ............. 12

Pruning Roots ............... 13

Placing Trees ................... 13

Dynamiting for Planting.......... 13

Benefits ...................... 14

When to Dynamite............ 14

Amounts to Use.................. 14

Object of Dynamiting.......... 15

Directions ................. 15

Preparing the Charge......... 15

Frozen Dynamite ........... 16

Other Uses of Dynamite........... 16

Cost of Dynamiting............ 17

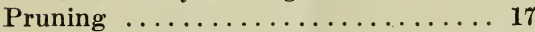

Time to Prune............... 17

Summer Pruning .................. 17

Height of Head.............. 17

Type of Head................... 18

Pruning at Planting Time........ 18

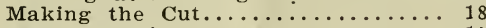

Apple, Pruning ............... 19

Pear, Pruning .............. 19

Peach, Pruning ................. 20

Plum, Pruning .............. 20

Cherry, Pruning ................. 20

Grape, Pruning .................. 20

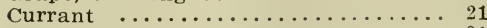

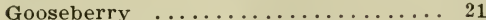

Raspberry, Black .............. 21

Raspberry, Red .............. 22

Blackberry .............. 22

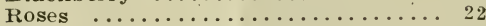

Shade Trees, Shrubs, Etc........ 22

Hedge, Pruning ................... 22

Renovating Old Orchards........ 22

Orchard Cultivation ..........24

Cover Crops ................ 25

Fertilizers ................. 26

Irrigation ................. 28

Orchard Heating ............ 28

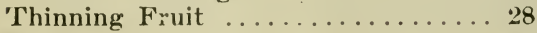

Pollination . . . . . . . . . . . . . . . 29

Reason for Not Bearing......... 29

Picking and Packing........... 30

Marketing the Crop.............. 31

\section{BOOK II.}

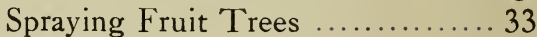

Spraying Pays .............. 33

Essentials of Spraying......... 34

Section I.

Classifying Tree Pests........... 35

Spraying Before Bearing ........ 35

Apple ................. 36

Apple Insects .............. 36

Apple Diseases $\ldots \ldots \ldots \ldots \ldots \ldots \ldots \ldots .440$

Apple, General Treatment........ 42

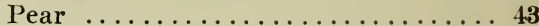

Pear Insects .............. 43

Pear Diseases ............... 44

Pear, General Treatment......... 44

Peach ................... 45

Peach Insects .............. 45

Peach Diseases $\ldots \ldots \ldots \ldots \ldots \ldots \ldots \ldots 446$

Peach, General Treatment........ 47

Plum ................. 47

Plum Insects $\ldots \ldots \ldots \ldots \ldots \ldots \ldots \ldots 47$

Plum Diseases ................. 48

Plum, General Treatment........ 48

Cherry .................. 48

Cherry Insects $\ldots \ldots \ldots \ldots \ldots \ldots \ldots 48$

Cherry Diseases ................ 48

Cherry, General Treatment....... 48

Quince ................... 49

Quince Insects .............. 49

Quince Diseases ............... 49

Quince, General Treatment......... 49

Grape .................... 49

Grape Insects $\ldots \ldots \ldots \ldots \ldots \ldots \ldots 50$

Grape Diseases ............. 51

Grape, General Treatment........... 51

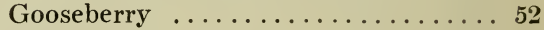

Currant ................... 52

Raspberry .................. 52

Blackberry ................ 53

Shade Trees ................ 53

Roses ................... 53

Insecticides $\ldots \ldots \ldots \ldots \ldots \ldots \ldots \ldots 54$

For Biting or Chewing Insects..... Arsenate of Lead............ 54

Hellebore ................. 54

For Sucking Insects..........

Whale Oil Soap.............. 54

Kerosene Emulsion............. 54

Tobacco Extracts............. 55

Fungicides ....................... 55

Commercial Lime-Sulphur......... 55

Home-made Lime-Sulphur........ 57

Bordeaux Mixture.................. 57

Self-Boiling Lime-Sulphur......... 58

Ammoniacal Copper Carbonate..... 59

Combination Sprays ........... 59

Spraying Machinery ........... 59

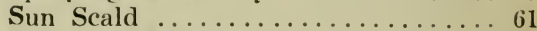

Mice and Rabbits............61 


\section{$\begin{array}{llllllllllll} & n & t & r & o & d & u & c & t & o & r & y\end{array}$}

Some years ago, we established in our offices here at Louisiana, Mo., a Special Service Department in which we gathered together, trained, practical, scientific horticulture experts, our attempt being to combine the scientific and the practical. The vastly increased service rendered by this Department is ample evidence of its unqualified success.

In this book, we have recorded, as far as possible, our own practical experience of four generations, combined with the results of experiments, tests and research work carried on throughout this and other countries.

The evolution of horticulture and the rapid progress made in recent years, particularly in spraying, has outstripped all available publications, and it is our endeavor to offer to the fruit growers, horticulturists and others interested in fruit culture, the only book containing the latest, most up-to-date information on orchard culture and orchard methods. We have endeavored to treat each subject in an easy-to-understand manner, in its logical order, beginning when the trees are selected and planted, and taking up various problems that the fruit grower will meet, even advising the most satisfactory and most profitable methods of marketing the fruit.

Our Special Service Department includes men of wide experience-men who are experts in orchard and nursery work. These men will gladly assist you in

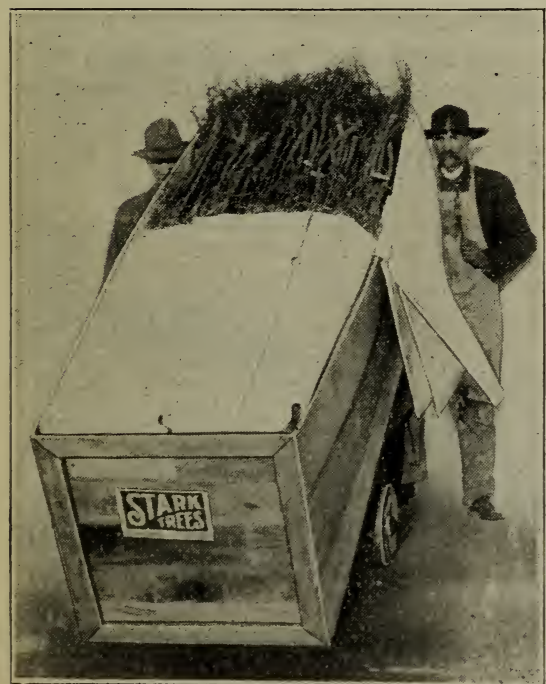

Stark Pacling Method.

Box lined with heavy paper-protection from drying. Moist fibre and moss around roots. solving your problems. This service is given free and without obligation. All literature issued by this Department, including bulletins, Year Books, and various treatises on horticulture, will be forwarded free upon request.

Stark Bros. Nurseries \& Orchards Co. have been growing trees since 1816nearly a century of experience. In our files and archives we have stored away a vast amount of horticultural knowledge and much has been handed down from father to son for over a century. From a small beginning, we have grown and prospered until Stark Bros. have the largest and most complete nursery establishment in the world.

\section{The Stark Method of Packing}

The packing methods, originated by us absolutely insure safe arrival of stock. If there were a better way to pack trees, we would pack that way, but experience 


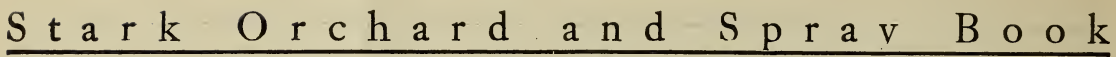

has shown that the Stark method is best. We use strong, durable boxes, lined with heavy paper and all trees are packed in damp fiber and moss.

We annually ship large quantities of stock to foreign countries-Australia, India, New Zealand, Alaska, Korea, China, South America, Europe, etc. The Stark method always stands the test, even across the Equator, and these trees are planted with entire success.

\section{Growing Quality Trees}

From the very beginning our life work has been to upbuild the great science of horticulture. We have been pioneers in advocating the planting of proven, high quality varieties of fruit and better fruit trees. We have found by pracitcal experience that in growing the different kinds of trees, different soils and different climatic conditions are required to grow them to the highest degree of perfection. To this end, we have established branch nurseries in many different states throughout the country, growing at each nursery, the kind of trees best adapted to that particular soil and climate.

By following this policy, we are able to offer to the planters of America the best trees that can possibly be grown by up-to-date nursery science and modern methods. Stark Trees are propagated only from whole root stocks, made from best American and French seedlings. Trees grown in this way make long-lived, vigorous orchard trees. No matter where you buy your trees, accept nothing but whole root trees.

"Grow the best trees that can be grown, sell them at a fair price and satisfy every customer," that's the one Stark policy-the foundation on which our success has been built. Good trees, trees that live and grow and bear good fruit, sold at an honest price have made us friends and customers by the tens of thousands

\section{STARK BROS. NURSERIES \& ORCHARDS CO.} Louisiana, Missouri, U. S. A.

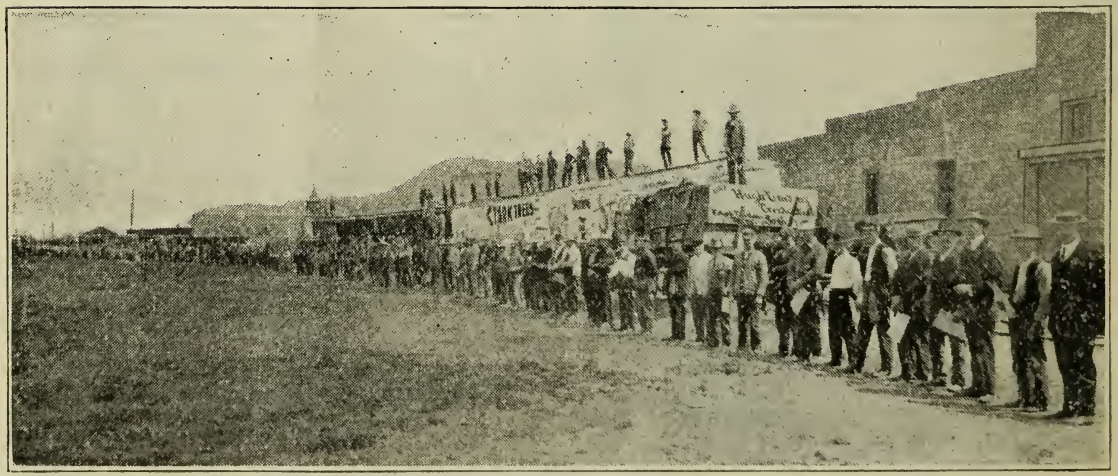

View of Stark Bros. Nurseries, at Louisiana, Mo.

A portion of Stark Bros. Nurserymen. whose practical experience, research work and tests have made possible the publication of the Stark Orchard and Spray Buck 


\section{Book I.}

\section{Planting and Growing Orchards}

\section{Growing of Quality Fruits}

One of the most important points to consider in planting an orchard is the selection of rarieties. The apple-consuming public appreciates quality in fruit and is willing to pay for it. Consumers will not accept such poor sorts as Ben Davis, Missouri Pippin, etc, but demand high quality rarieties, like Stark Delicious, Stayman Winesap, Stark King David, Jonathan, etc. When Ben Davis will not pay for the picking, the quality sorts command high prices on the market. The fact that practically all new orchards are being set to these quality varieties is overwhelming proof that progressive orchardists realize the importance of selecting high quality varieties.

\section{When to Plant}

Fall planting is advisable where the winters are not extremely severe. Some of the advantages of fall planting are: first, it is a convenient time-generally less work on the farm and in the orchard;second, the tree heals the cut roots, establishes itself and is ready to start growth early in the spring, thus acquiring strength to withstand summer droughts; third, the buyer gets the pick of the nursery trees and does not run the risk of the supply of any of the desired varieties being exhausted.

Stock planted in the spring should be set out early. If you decide, after buying trees in fall, not to plant until spring, heel in the trees (see page 8 for directions). This, if well done, will keep them in perfect condition.
Planting season is not regulated by date or by planter's location, but by condition of stock to be planted. Stark Bros. method of growing, packing, and shipping trees assures arrival in proper planting condition. We annually ship thousands of trees to planters in the South, weeks after their spring has opened and these trees are planted with entire success.

"It has been our experience that a fallplanted tree does at least fifty per cent better the first year than one that has been planted in the spring."-C. A. McCue, Horticulturist, Del. Agri. Exp. Station.

"Over a large part of this country fallplanting is practicable. The ground is usually in better cordition and the wounds on the roots heal and rootlets are furmed ready for growth at the first impulse if spring. If planting cannot be done in the fall for any reason get the trees and heel them in until early spring, then they will be on hand just when they are needed." - Prof. H. E. Van Deman, ex-United States Pomologist.

"For mild climates I much prefer fallplanting. Where climate is too rigorous for fall-planting, I prefer to get my trees in the fall and heel them in for spring planting." F. Walden, Editor "Ranch."

\section{Age of Trees}

Large commercial planters have almost entirely given up planting anything but one-year trees. After conducting extensive experimental work and practical tests in our own orchards and seeing the results of experiments carried on by horticulturists and orchardists throughout the country, we were convinced long ago that one-year trees are best; and as we grow them they are the ideal orchard trees.

The famous western fruit-growing valleys, as well as many other orchard 


\section{S tarkOrchardand Spray B o ok}

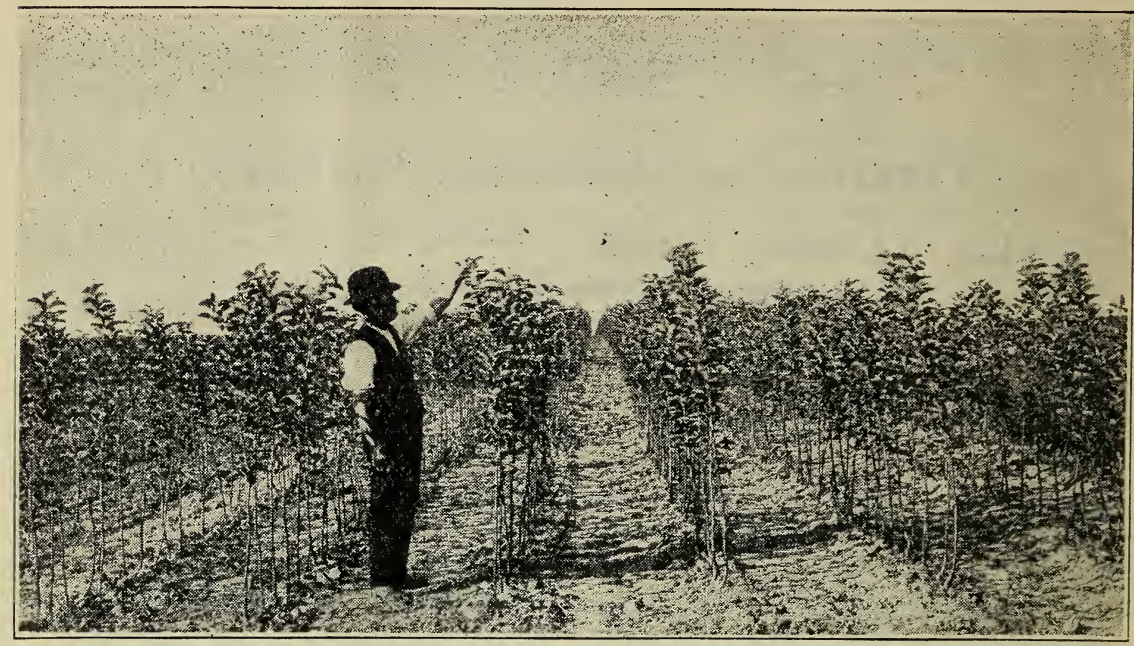

Stark Bros. One-Year Apple Trees.

These famous Ozark-Mountain-grown apple trees are grown where soil and climatic conditions are ideal for producing strong, vigorous apple trees with incomparable root systems.

sections, are unanswerable arguments in favor of one-year trees. The foundations of practically all these wonderful orchards are one-year trees, and there an older tree can hardly be given away.

Advantages of the one-year tree:

1. Cheaper to buy-lessens planter's original investment.

2. Handled and planted at less expense than an older, bulkier tree.

3. Withstands the shock of transplanting better than an older tree.

4. Establishes itself readily and grows more thriftily.

5. The one-year tree can be pruned and trained to the exact form desired by the grower-one of the strongest arguments in its favor. In the case of an older tree, the head is formed in the nursery row.

6. A one-year tree will soon overtake and will bear just as soon as an older trec planted at the same time.
"I fully agree with you in regard to planting one-year trees. In answering the many inquiries received at this office, $m y$ advice is always in favor of the one-year tree, especially if well grown and on sound, healthy roots. Fully so per cent of all apple trees now planted for commercial purposes are of this age. The low head is now almost universally preferred, and the one-year tree affords best concitions for forming such heads. The shock in transplanting is much less than in older trees."-G. B. Brackett, U. S. Pomologist.

"It is our belief here at the Station that the cne-year-old tree is the better, more economical, and the safer tree to plant."-J. C. Whitten, Prof. of Horticulture, Missouri State University.

"I am very much in favor of yearling trees, but it seems difficult $t$, get them in Ohio. There is no question but that they are the best trees to plant when well grown. The future framework of the tree may be placed exactly where the grower wishes it. With older trees this is quite impossible." - Wendell Paddock, Prof. of Horticulture, Ohio University.

"One-year trees, first, last and all the time here for us-two-year abut knocked out except in small lots to people who do not know reasons. The one-year, less in frelght, easier to plant, car he haded to suit, grows better, etc."-C. S. Scott, Monroe Co., West Virginia. 


\section{$\underline{\text { Stark Orahard a n d Spray B o ok }}$}

\section{Orchard Lands}

Site. As a rule, rolling or gently sloping land is best for the orchard. This insures good air drainage. Avoid "pockets," because cold air, being heavier than warm air, will sink into the pockets and increase the danger of frost injury.

Soils. In general, any good farm soil is all right for fruit growing. Avoid wet spots; a good, deep, well-drained soil is preferable. The various fruits show a preference for certain types, although they will thrive on widely varied soils. For instance, the apple will succeed on a light, sandy loam, but it will also produce excellent crops on heary clay soils. But, as a rule, apple does best on a medium soil-neither too light nor too heavy.

Humus is one of the most important constituents of soils. It dissolves the mineral plant foods and makes them available to the plant roots and also increases water-holding capacity of the soil. Humus consists of decayed organic matter, such as rotted leaves and manure, plowed under cover crops, etc., and it contains important plant foods. The maintenance of the humus supply in soils is absolutely necessary if profitable crops are grown. (See page 25 under Cover Crops for best methods of maintaining humus supply.)

The three general classes of soils are: 1, Light (Sandy) soils; 2, Medium (Loamy) soils; and 3, Heavy (Clay) soils.

The management of sandy soils is largely a matter of maintaining the humus content. These soils are liable to get "burnt out", but this can be prevented or remedied by plowing under cover crops or stable manure. A sandy soil usually produces fruit of high color. These soils dry out very quickly, thus allowing cultivation soon after rains and rery early in the spring.

Loamy soils as a rule are best adapted for growing all kinds of fruits. They are the easiest to handle and keep fertile. Generally, they have sufficient of the necessary mineral elements, hence rarely require commercial fertilizers. On rich soils the wood growth of the trees is liable to continue late into the fall, therefore, cultivation should be stopped soon enough to allow the wood to mature before severe weather.

Clay soils are the most difficult to handle. They must be plowed and cultivated at just the right time. If plowed too wet, they are liable to "puddle", forming big clods; if allowed to get too dry, they will bake. Maintaining a sufficient amount of humus, by the use of cover crops and manure, in connection with frequent cultivations, is the key to the successful operation of clay soils.

When soils bake a large amount of soil moisture is lost by evaporation, therefore, the crust should be broken very soon after each rain. Try to maintain a fine dust mulch about three or four inches deep, by constant cultivation. This method of management will conserve the moisture. Plow deeply and harrow thoroughly. Frequent cultivation is the secret of moisture conservation. (See page 24 for details of cultivation.)

Drainage. Low, wet land is not adapted to fruit growing. Provide sufficient surface drainage to carry off excess water. Tile drains are often desirable and will greatly benefit the orchard and especially heavy, wet, clay soils.

\section{Arrival of Trees}

As soon as the trees arrive, unpack immediately, carefully shaking out all 


\section{$\underline{\mathrm{Stark} O \mathrm{O} \text { ch a r d a n d S p r a y B o ok }}$}

packing; if possible, plant at once. However, if they arrive during frosty weather, place them unopened in a cool, dry cellar, but free from frost. When the weather moderates, unpack as above. Don't expose roots to sun, air, wind, or frost.

If planting is to be made within a short time, trees can be left in the box in a cool place away from the sun.

If the trees have been miscarried or delayed in shipment and have become badly shriveled, bury them in moist earth and pour on water, keeping them wet for a few days. When the trees have become plump and fresh, plant at once.

Heeling In. If ground is not ready to plant when trees arrive, unpack and heel in. A good plan which many fruit growers prefer is to order stock in fall and heel in until the next spring, when the trees will be in good condition and will be on hand when you are ready to plant. When heeling in, choose fine, loose soil, in a well-drained location, preferably on a ridge. Dig a trench two feet deep, throwing dirt forward so as to make a sloping bank, on which lay the trees slanting, with roots in trench. Be sure to cut the bundles open, shake out all the packing and lay trees in

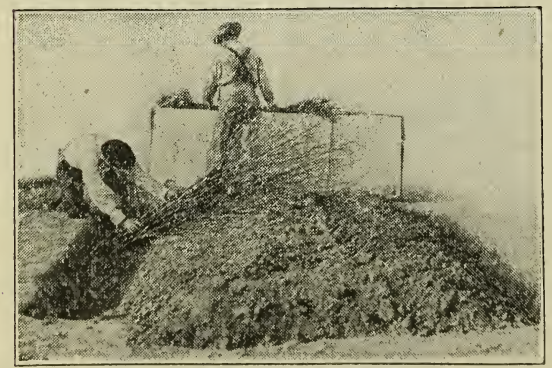

Heeling in Trees.

A layer of trees heeled in. starting second layer. Taken directly from box-no exposure. thin layers. Then throw a layer of dirt on the roots and on the whole length of trees to the very tips. Work the soil in weil around the roots and tops, packing the dirt firmly. Removal of this soil (trench) forms another trench parallel to the first, which in turn is filled with trees and covered with dirt. Add as many layers as necessary to dispose of all the trees, with dirt between each layer. Do not be afraid of putting on too much dirt. Smooth the side so as to turn off water and dig trenches entirely around the mound, allowing for a ditch to carry off the surface water. Cover the mound with dead leaves or evergreen boughs to prevent the alternate freezing and thawing of winter.

Varieties can be kept separate by stakes which should project above pile of trees.

\section{Planting}

Preparing the Land. The best preparation of land for planting trees is to plow under a heavy coating of manure the fall before planting. Plow deeply, but do not turn up much of the subsoil. If the soil seems to need further treatment, at planting time, a good thorough discing will probably be sufficient. The ground should be prepared just as well as for a farm crop. (For use of dynamite for tree planting see page 13.)

Planting Plans. The question of planting plans must be determined by the grower. We give the merits and the faults of the two main plans as we have found them.

These plans are:first, the square plan; second, the triangular (also called hexagonal) plan.

The square plan has been used largely in the past. Its advantages are: first, easy to lay out; second, well adapted to 


\section{Stark Orchard and Spray B o o k}

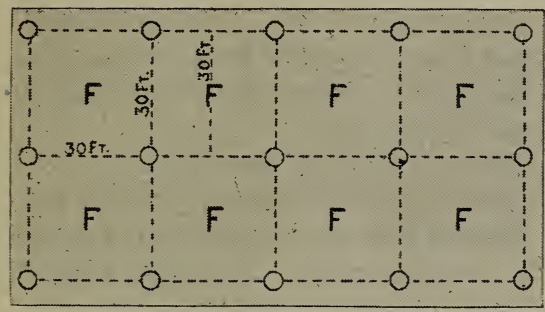

Square Plan.

Circle indicates position of permanent trees. " $F$ "' indicates filler trees.

the use of fillers; third, ease of cultivation. Its main disadvantage is that it is not an economical use of ground (15\% more trees can be planted by triangular plan than by square plan). Where fillers are used, the square plan is simpler. Plant fillers in center of each square. (See diagram.) In this way you have the same number of fillers as permanents.

The "triangular plan," which is being largely used by commercial planters and allows more trees to the acre than the square plan, is explained by diagram above. In the middle row the trees are opposite the spaces of the adjacent rows. Thus there is no unused space in the center as there is in the square plan. The main advantage of the triangular method is economy of land. Also, it permits cultivation or irrigation in three directions. Uses same number of fillers as permanents, but the fi.lers are closer to permanents, and will crowd more quickly than in the square method. We advise the use of the triangular plan.

Rule. To find the number of trees or plants required to the acre when planted by the square plan, multiply the sides of the square or rectangle together. Divide the product into 43,560 (which is the number of square feet in one acre).

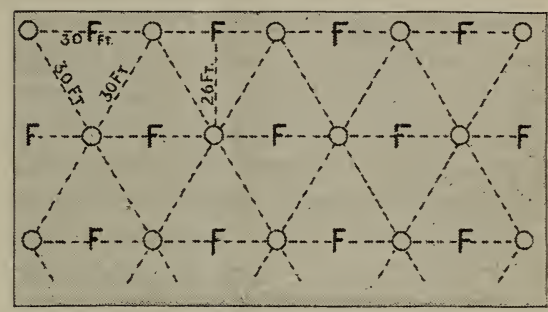

Triangular (Hexagonal) Plan.

Trees same distance apart; takes 15 per cent more trees than square plan.

For example:

(Trees to be planted 30 feet apart.)

$30 \times 30=900$.

$43,560 \div 900=49$, number of trees per acre by the square plan.

To find number of trees when planted at the same distance by the triangular plan, add $15 \%$ to the number required by the square plan.

$15 \%$ of $49=7$.

$49+7=56$, number of trees to the acre when planted by the triangular plan, 30 feet apart.

The following table will give number of trees per acre when set at different distances :

\section{Planting Distance}

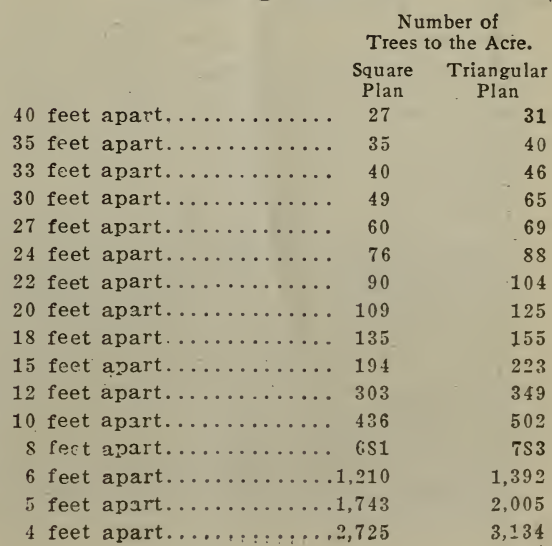




\section{Stark Orchardand Spray B o o k}

Distance Apart. Planting distance will vary in different localities and under different climatic and soil conditions. Some varieties should be planted closer than others. Orchards on very strong soil should be slightly farther apart than on medium soil. If the orchardist wishes to set trees closer than we advise, he can do so, if he will keep trees well pruned in.

Proper distances to plant are as follows:

Apple: 24 to $33 \mathrm{ft}$. apart. We advise 30 feet as being the most satisfactory.

Apricot: 16 to 20 feet apart.

Asparagus: 1 to 2 feet between plants, in rows 3 to $31 / 2$ feet apart.

Blackberries: 3 to 4 feet between plants, in rows 6 to 8 feet apart.

Cherry: (Sour sorts) 16 to 20 feet apart.

Cherry: (Sweet sorts) 20 to 27 feet apart.

Currant: 4 feet between plants, in rows 5 feet apart.

Gooseberries: 4 feet between plants, in rows 5 feet apart.

Grape: 8 to 10 feet apart, or 8 feet apart in row, with rows 10 to 12 feet apart.

Hedge Plants: 1 to 2 feet apart. (To get a thick hedge quickly, plant two rows 10 inches apart, with plants alternating-that is, no two plants opposite.)

Mulberries: 22 to 28 feet apart.

Pecan: 35 to 40 feet apart.

Peach: 16 to 20 feet apart.

Pear, Standard: 20 to 27 feet apart.

Pear, Dwarf: 10 to 16 feet apart.

Plum: 15 to 20 feet apart. (On rich soil Japanese sorts should be planted at least 20 feet apart.

Quince: 10 to 16 feet apart.

Raspberries: (Black) 3 feet between plants, in rows 6 to 8 feet apart.
Raspberries: (Red) 3 feet between plants, in rows 5 to 6 feet apart.

Rhubarb: 3 feet between plants, in rows 4 feet apart.

Roses: 2 to $2^{1 / 2}$ feet apart.

Walnut: 35 to 40 feet apart.

Pollination. Do not plant solid blocks of a single variety. In order to assure cross-pollination of the blossoms, do not plant more than four rows of any one variety in a solid block-that is, plant four rows of one variety, then four rows of another variety, etc. (For full details on pollination, see page 29.)

For commercial orchards, we advise that only three or four varieties of winter apples be planted in a single orchard.

Fillers. The practice of planting fillers in the orchard is strongly advised by leading authorities and practical orchardists. Fillers are early bearing and dwarfish-growing varieties of apple, cherry, peach trees, etc., which are planted between the rows of the permanent trees. The profits from the fillers will very often pay for the orchard before it is necessary to remove the fillers. The use of fillers allows the orchardist to get quick returns, and will furnish working capital to care for the orchard until the permanent trees come into bearing. Also, the high price of land in certain sections makes the grower consider how he can get the greatest profits from a small acreage. (See diagram, page 9. F indicates position of filler.)

The only objection to the use of fillers is that many growers will not cut them out in time. They must be removed before they begin to crowd the permanent trees. Young bearing varieties of apples are especially advised as fillers. This does not mean that they are short-lived, because they are equally as good when used as permanent trees. 


\section{Stark Orchard a nd Spray B o o k}

Varieties recommended for fillers:

Stark King David (one of the best), Wealthy, Liveland Raspberry, Wilson Red June, Summer Champion, Yellow Transparent, Duchess, Black Ben, McIntosh Red, Rome Beauty, Grimes Golden, Jonathan, Wagener.

Cherries also make excellent fillers. They are hardy and bear very young, are always in demand on the market and produce big profits. Varieties which grow medium size in tree, such as Montmorency, Suda Hardy and Dyehouse, are well adapted for fillers.

Many large commercial growers pay for their apple orchards by growing peach fillers. The peaches begin to bear very early, and are ready to remove before they crowd the apples.

Intercropping. Intercropping young orchards with small fruits is recommended. Currants, gooseberries, raspberries, and blackberries are all excellent for this purpose. These can be grown in between the rows even when fillers are used. Other cultivated crops, such as potatoes, can also be grown.

Do not grow, in the orchard, crops like timothy or grain. They will rob the soil of plant foods, and will return nothing to it; also, they use up large quantities of moisture.

Crops, such as clover, cowpeas, vetch and rye, are very beneficial when grown in the orchard as cover crops and plowed under. (See page 25.)

Laying Out the Orchard. The rows should be straight and correctly spaced, not only on account of the appearance, but to make the orchard operations easier. There are numerous ways of laying out the orchard, and the planter will have to determine the one best adapted and most practical for his conditions.

In planting by the square plan, the ends and sides of the field are staked off at intervals equal to distance between trees. Then, deep furrows should be plowed from stakes on one end to corresponding stakes on the other end. Then, plow furrows across the field between corresponding stakes on the sides. Wherever the furrows intersect is the position for a tree. This saves time by helping to dig the holes. To assist the man with the plow, stakes should be set in line between the end stakes. By sighting along these stakes the line can be kept fairly straight.

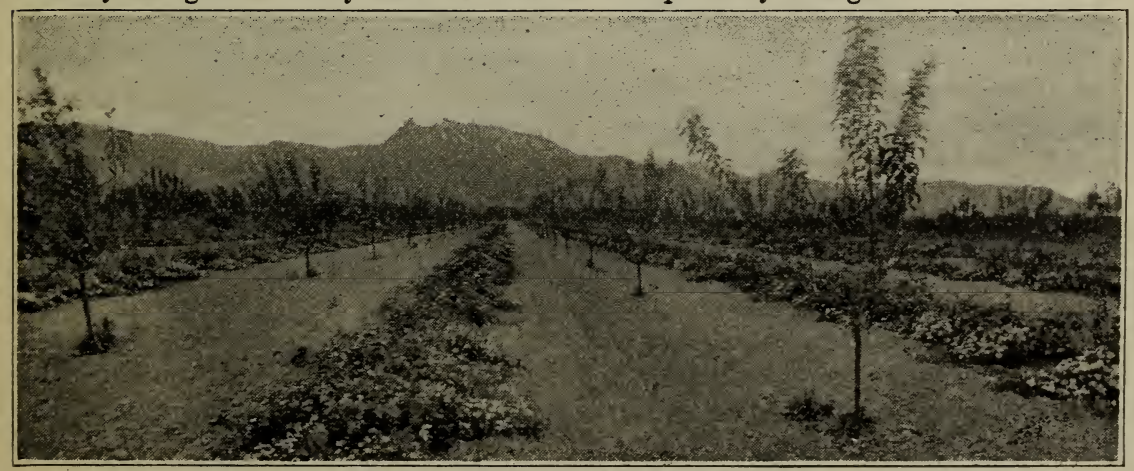

trees are young produces big profits-often paying for the orchard. 


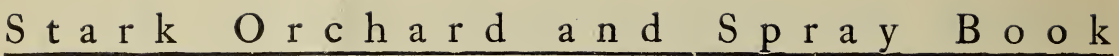

Another method especially applicable to small orchards is the wire method. Stakes are set on opposite ends of the field at intervals equal to distance between rows, beginning at the desired distance from the fence, usually 15 to 20 feet. Then, a wire is stretched across the field between corresponding stakes. The wire can be marked by pieces of small wire wrapped and soldered to prevent slipping-these markers to be at intervals along the wire equal to the distances between trees. Set stakes at point indicated by the markers. After staking one row, move to the next, and so on.

In setting trees by the triangular $p^{\prime}$ an, stake the ends of the field at intervals equal to distance between rows, which will be less than the distance between trees (see diagram, page 9, for explanation). See following table for approximate distances. For example, when trees are 30 feet apart, the rows will be 26 feet wide.

\section{Triangular Plan-Width of Rows \\ Distance Between Trees Distance Between Rows \\ $23 \mathrm{ft}$. corresponds to $28 \mathrm{ft}$. 7 inches.}

$30 \mathrm{ft}$. corresponds to $26 \mathrm{ft}$.

$27 \mathrm{ft}$. corresponds to $23 \mathrm{ft}$. 3 inches.

$24 \mathrm{ft}$. corresponds to $20 \mathrm{ft}$. 9 inches.

$22 \mathrm{ft}$. corresponds to $19 \mathrm{ft}$.

$20 \mathrm{ft}$. corresponds to $17 \mathrm{ft}$. 4 inches.

$18 \mathrm{ft}$. corresponds to $15 \mathrm{ft} .8$ inches.

$15 \mathrm{ft}$. corresponds to $13 \mathrm{ft}$.

Lay off the rows with a plow, or use a wire. After staking the first row, measure along the row half the distance between the first and second stakes. Mark this point and place a stake in the second row exactly opposite. (In order to get the exact point in the second row, use the wire triangle method described in the following paragraph.) This is the position for the first tree of the second row. Then, stake the rest of the row at the required intervals. The third row and all odd numbered rows will correspond to the first row; all even numbered rows will correspond to the second row.

Another method for locating position for trees in the triangular plan is as follows: Make a triangle of heavy wire, each sice of which is the same length as the distance between trees. Each corner of the triangle is formed by an iron ring. Stake the first row at intervals equal to distance between the trees. To get the position of the first stake in the second row, three men take the wire triangle, each man at one corner, and two of them with their rings held at the first and second stakes in the first row enable the third man, by pulling the wires taut, to locate the first tree in the second row. Moving to the second and third stakes of the first row, he locates, by means of the triangle, the second stake in the second row, and so on across the field.

Digging the Holes. The land should be well loosened and smooth on the surface. Dig the $h^{\prime}$ s large enough to receive the roots easily, without crowding or bending. In digging the holes, keep the top soil separate from the bottom soil.

Dynamite is used for blowing the holes in tree planting and gives excellent results. For detailed directions on the use of dynamite see page 13.

Distributing Trees. When distributing the tree in field, keep the roots protected from drying by covering with wet cloth, or packing. One good method which has been used with excellent success is the following: Place a large tank or barrel $\mathrm{c}^{-}$a wagon, put in the trees with enough water or very thin mud in 
the bottom to protect roots from drying. The man driving can trim the roots and hand to the planters.

Pruning the Roots. Root pruning is an essential to best results in planting trees. This consists in trimming off the broken and bruised ends. Any long, slender roots should be cut back to about 8 inches. Make a slanting cut with a sharp knife, cutting from the under side so the cut surface will rest against the soil. Cut off the ends of any bruised roots and trim off any dry, fibrous roots. A careful pruning of the roots tends to prevent "root rot" a disease responsible for the loss of many young trees in certain sections of the South.

Placing the Trees. In places where there are strong winds, orchardists follow the practice of leaning the tree slightly toward the direction of the prevailing wind. Leaning the tree toward the southwest enables it to stand up against the wind and protects it from sunscald. However, it is probably not necessary to lean the tree if the heavy side is planted toward the wind. To determine the heavy side of a tree, balance in the hand, and the side which settles next the hand is the heavy side. Plant the heavy side toward the prevailing wind.

In planting, one man should hold the tree in position, firming the dirt which the other man throws in the hole. Plant the tree an inch deeper than in the nursery row. The dark ring on the base of trunk shows the depth the tree stood in the nursery. If the soil is one which dries out quickly, plant two inches deeper. Dwarf pear, however, should be planted five to six inches deeper than they stood in the nursery.

Never crowd or bend the roots. Firming the dirt around the roots is of great importance. Lack of firming is largely responsible for the failure of many trees to live. Holding the tree in position, throw in some of the best top soil and work in well around the roots. Leave no air pockets. Tramp and pound the soil in hard until the hole is three-quarters full. At this point, if the soil is very dry, it will be beneficial to add several gallons of water. Let the water sink in, then, fill up the hole with loose dirt, but do not tramp after watering. Be sure that the top two or three inches of soil consists of loose, untramped soil, which will serve as a mulch and prevent excess evaporation. Some growers place well-rotted manure around the base of the tree after planting. This acts as a mulch and also furnishes plant food for the tree. Do not place manure in direct contact with the trunk, and never put it in the hole, because it will make air pockets and cause the roots to dry out.

Just as soon as the trees are planted, make a careful map or record of your orchard, numbering the rows and trees, so that, in after years, you can locate all of the different varieties. Immediately after making your record, remove all labels from the trees. If allowed to remain on the trees, the wire will cut into the growing branch and, eventually, cause it to break off.

\section{Dynamiting for Planting}

The use of dynamite in connection with the planting of trees is, practically, a recent discovery, and it is of vital importance to the fruit growing industry of the country. Our Special Service Department thoroughly investigated and tested dynamiting for tree planting. We consider dynamite very beneficial in preparing soil for tree planting, especially in dense subsoils, such as heavy clay, 
hardpan, gravelly, stony, and similar soils. In fact, all soils will be benefited by the intelligent use of dynamite, except sandy soils, which are too loose to retain sufficient moisture unless underlaid with impervious subsoil.

Benefits. Some of the benefits of dynamiting are as follows: The subsoil is shattered and broken up, giving the roots a much greater feeding area and allowing the tap root to go downward. The presence of hardpan a few feet below the surface tends to stop the downward growth of roots and forces them outward, which condition does not give a deep anchorage to the tree. Dynamited soil will quickly absorb large quantities of water. thus allowing the tree to withstand severe drought. It gives the young tree a better chance to become established and start a vigorous growth. The failure of trees to live is due mainly to small, spade-dug holes and lack of firming the soil around the roots. Dynamite will correct this fault to a large extent. It loosens up the soil for many feet around, thus furnishing the best possible conditions for starting a vigorous, quick root growth. The first few months after planting usually decides if a tree is to succeed or fail, and a tree planted with dynamite certainly has a great advantage.

Often a fruit grower wants to plant his trees, but finds that his ground has not been plowed and prepared. Dynamite can be used to blow the holes if the soil is dry enough. A charge of dynamite is exploded where each tree is to be planted. Use a pole to push down in the dynamited hole so as to be sure to fill up all air spaces or pot-holes. If air spaces are allowed to remain, they will cause roots of the trees to dry out. The dynamite shatters and loosens the soil so that after the soil has settled the tree can be planted and start a thrifty growth at once. Then the ground in between the rows can later be plowed and cultivated. This plan often permits the fruit grower to get his trees planted just one year sooner, which means that his first crop will be harvested twelve months earlier.

When to Dynamite. The best time to dynamite for tree planting is in late summer or fall, when the soil is dry. Never dynamite wet ground-always wait until the soil will pulverize-not paste. Dynamiting wet soils has the same effect on the subsoil as plowing wet ground has on the upper soil. Furthermo - when the ground is too wet, explosion is liable to form pockets or pot-holes, which will make air spaces and cause the roots to dry out. If you intend planting in the spring, dynamite the fall previous. Then the rains and freezing of the winter will cause the ground to settle somewhat, thus avoiding all danger of air spaces. A stick or pole can be used to push the dirt down and fill up any possible air holes.

Amounts to Use. Local conditions determine the amounts and kinds of dynamite necessary, varying with the type of soil, subsoil, and the work to be done. Dynamite can be purchased in various grades and strength, usually from $20 \%$ to $60 \%$. The lower the per cent of strength the slower the explosion, but greater the heaving or lifting power. The nature of the ground is determined by boring with an earth auger. We can refer you to parties who sell augers especially adapted to dynamiting work. In this way it is possible to ascertain the exact depth of the hardpan or the different subsoils that may be present. In nearly all soils of ordinary density, one- 


\section{Stark Orchard a nd Spray B o ok}

half stick of $20 \%$ dynamite is about right for tree planting, and with it a No. 6 standard cap should be used. In ground where heavy hardpan, or rocky, gravelly subsoils are prevalent, $40 \%$ strength dynamite is advisable. The depth of the hole also governs the amount of dynamite to be used-the deeper the hole, the more dynamite. The $20 \%$ strength dynamite does admirable work as it has slower action and better pulverizes the ground than the higher percents.

Object of Dynamiting. In dynamiting, the aim should be to get the maximum puverizing effect without blowing out a big hole. After the explosion a low, cone-shaped mound should remain where the tree is to be planted. Do not try to blow out a large hole-this is a waste of dynamite and will not give as good results as when the ground is merely lifted up and drops back in a cone-shaped mound. Soil should be allowed to settle for several weeks at least and it is better if it can remain orer winter before planting.

Directions. Dynamite is not as dangerous and likely to explode as the arerage person imagines. However, caution is advisable at all times. Note the list of Don'ts, page 16.

Preparing the Charge. With an earth auger or an iron bar begin your hole, which does not necessarily have to be more than two inches in diameter, and as deep as necessary, depending upon the work to be done. An average depth is $1 \frac{1}{2}$ to 3 feet. The bottom of the hole should reach within a few inches of the hardpan or dense subsoil, if there is one. When the hole has reached the desired depth, prepare the load or cartridge as follows:
Break a stick in half, which is usually enough (first cutting through the paper with a sharp knife), and cut a piece of fuse about four inches longer than the hole is deep. Insert one end of the fuse in the end of the cap and crimp it with the pliers or crimper provided for that purpose, near the open end (Don't crimp near the head). With a narrow, pointed instrument, usually one prong of the pliers or crimper, push a hole diagonally into the side of the dynamite stick or directly in at the end, making same about two inches deep. Within this push the dynamite cap to which the fuse is attached. With a string tie the fuse and stick so that it will not slip out when lowered into the hole, and the cartridge is complete. Lower the charge

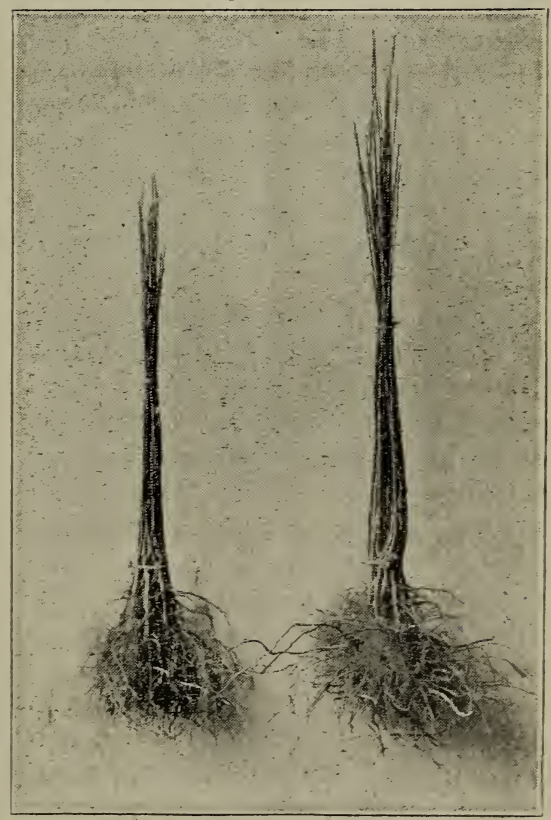

Stark Trees.

Magnificent roots of one-year apple trees. These make the ideal orchard foundation. 


\section{Stark Orchard and Spray B o ok}

in the hole and force firmly with a wooden stick (not metal), and if it does not reach the bottom, gently press as far as possible: Several handfuls of dirt should then be thrown in and this tamped with a wooden stick, then more dirt and more tamping until the hole is filled to the ground level. The wooden stick or pole used in tamping should be long, so that the man tamping can stand to one side-not directly over the hole.

After removing all explosives, dynamite sticks, dynamite caps, implements, etc., to a reasonable distance, see that all persons are out of the way and then, with a pocket knife, split the end of the fuse and light with a match. A few seconds will elapse, which will give ample time to retreat to a safe distance.

Important. The actual work with dynamite is simple but the persons handling dynamite should not become careless. The following Don'ts, if heeded, will prevent $90 \%$ of the accidents:

Don't expose dynamite to rain or allow it to get water soaked, as this weakens it.

Don't leave the caps of dynamite near the place where you are firing a charge.

Don't carry the caps loosely in a pocket, or in a large box where they are liable to shake-the caps are very sensitive.

Don't crimp the cap with your teetha special crimper can be procured from the Dynamite Company.

Don't tamp the charge with a steel or iron implement-use a wooden pole.

Don't cut a stick of dynamite-merely cut through the outside paper with a sharp knife and break it with the hands.

Don't handle old dynamite carelessly -it explodes more easily than new dynamite.
Don't attempt to dynamite in wet soils-it has a bad effect on the ground and will give unsatisfactory results.

Don't expect a charge to go off immediately after lighting-always wait a reasonable length of time.

Don't rush; steadiness and coolness are best.

Don't forget to make the other fellow be careful.

Don't smoke when working around dynamite and caps.

Frozen Dynamite. Most dynamites, except low freezing dynamite, will freezc at about 45 degrees Fahrenheit. Low freezing dynamite will seldom freeze at the freezing point of water, and often will not freeze at much lower temperatures if not exposed too long. Frozen dynamite can be thawed by placing the box in a pile of manure, where it will soften in a few hours. If no manure is available, it should be thawed in the following manner: Secure a double boiler (one kettle within another). The larger, or outside, kettle, fill with warm water. Place the dynamite within the inner or smaller kettle. Do not allow the water to become warmer than the hand can stand. Do not put on the stove to heat, but pour in hot water.

Gloves should be worn when handling sticks of dynamite, especially when handling old dynamite. This will prevent many headaches caused by contact of the bare hands with chemicals used in the making of dynamite.

Other Uses of Dynamite. Dynamite is used to good advantage in vineyarts by placing a series of small charges between the rows, varying from one. to three feet in depth. This is a system of light subsoiling and will cause more vigorous growth and a heavier yield. 


\section{Stark Orch a r d a n d S p r a y B o o k}

Also dynamite is used with excellent results on old trees which have begun to bear smaller, less valuable crops. Explosions of several light charges at intervals around the tree-about seren to fifteen feet from the trunk-will loosen up the roots and give the tree more vigor. About four charges equally distributed about each tree is generally sufficient. Charges should be placed $1 \frac{1}{2}$ to 3 feet deep using a half stick of $20 \%$ dynamite. Do not explode the charge directly under the tree.

Cost of Dynamiting. The Du Pont Powder Company gives the following estimate on tree planting with dynamite, using Red Cross Extra, 20\% strength: "If dynamiting and blasting supplies are purchased at the agricultural schedule, the cost of explosives for planting a tree wi.l average about 6 cents; that is, for $1 / 4$ lb. of dynamite approximately $3 \frac{1}{2}$ cents, for a cap 1 cent, for fuse from 1 to $1 \frac{1}{2}$ cents, depending upon the length of it. Purchased in quantity, the cost will be considerably less."

In the short space of this chapter it is not possible to give specific instructions on the use of the many forms of dynamite. Therefore, it is advisable, when ascertaining your particular need of dynamite, to write reliable dynamite companies. Dynamite and powder companies maintain a special department for this service, and your inquiries to them will receive their careful attention and full advice.

\section{Pruning}

Do not neglect pruning-it is absolutely essential. Prune trees while young and later treatment will be much simpler. Pruning tends to increase vigor and fruitfulness; it allows sunlight to get in to the tree, giving better color to the fruit. Spraying, picking, cultiration, and other orchard operations are made easier by intelligent pruning.

Time to Prune. Ordinarily, the best time to prune is during mild days in the late winter or early spring before the buds swell. Pruning at this time tends to increase vigor of tree and promote wood growth. Do not prune too severely-it will cause water sprouts to develop and will check the formation of fruit buds.

Summer Pruning. Summer pruning is often resorted to when the tree is making too heavy a wood growth at the expense of fruitfulness. A moderate pruning at the height of the growing season (in June or July, depending on the season and latitude) checks the wood growth and causes the tree to throw its strength toward the formation of fruit buds.

Do not overdo summer pruning. Remove only a small amount of terminal (end) growth, just enough to check it. In many cases pinching back the terminal buds will be sufficient. Intelligent pruning will cause fruit spurs to form along the limbs instead of only at the ends of the branches, and the tree will be able to carry a much hearier load without breaking its branches.

Height of Head. Aim to produce a well-balanced tree with a low head. A low-headed tree is much easier and cheaper to pick, sprar, prune, and thin than a higher-headed tree. A lowheaded tree shades the branches and trunk, thus preventing sunscald. There is less danger from the action of the wind and less loss from windfalls on a low-headed than on a high-headed tree. Commercial planters realize the advantages of low heads and practically all trees planted now are being headed 


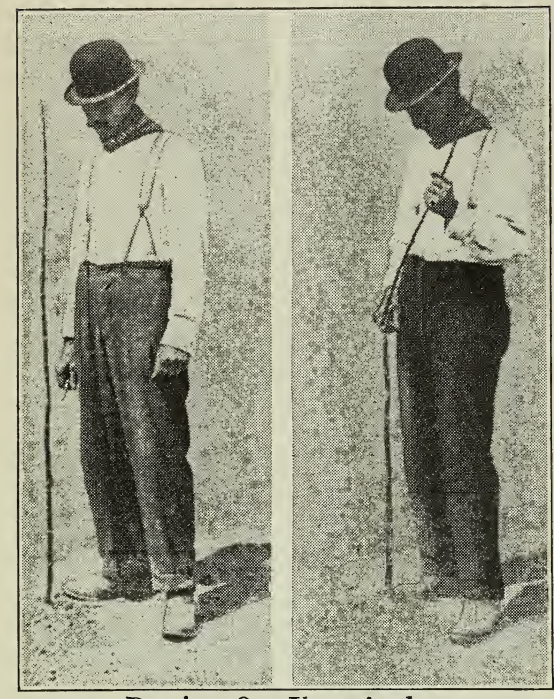

Pruning One-Year Apple.

Make a sloping cut just above a strong bud. Head apple trees low.

low. The main argument used in the past against a low-headed tree was that it interfered with cultivation. However, the height of head has very little to do with this. By correct pruning a tree can be made to grow sufficiently upright to permit thorough cultivation. To make a tree grow upright, prune to a bud or limb which points upward. To make tree spread out, prune to a bud which points outward from the middle of the tree. The up-to-date orchard cultivators permit close cultivation without injury to the limbs.

Prof. F. A. Waugh, in "The American Apple Orchard", says:

\footnotetext{
"Goneral horticultural opinion has undergone a great change in recent years. It has been a change favorable to lower heads. Low heads tend to prevent sunscald, in fact, nearly all the disorders to which tree trunks are liable, such as borers, frost cracks, etc."
}

Type of Head. There are two types used in the formation of the top of the orchard tree: First, the leader (pyramidal) type, which gives a high tree with one central leader and many side branches. This type has been largely used in the past but is being rapidly displaced by the open-head type. Second, the open (vase-shaped) head, in which the leader is removed and the remaining branches form a spreading tree with an open head. As a rule, the open head is better. The breaking of any one branch does not cause the loss of the whole tree. Also, the open, spreading head facilitates picking, spraying, and other orchard operations. However, some few varieties produce a better shaped tree if the leader is left. Whatever system you use, be sure to keep the head of the tree thinned out so as to admit the air and sunlight.

Pruning at Planting Time. Prune the top of the young tree as soon as planted -not before. Many of the roots were cut off when the tree was dug, and an equal proportion of the top should be removed. (This does not apply to cherry, which requires very little pruning.) When pruning, bear in mind that the various kinds of fruit trees have different habits of growth. The different varieties of any one fruit also vary largely. For instance, a Winesap is a very spreading, willowy grower, and should be pruned so as to encourage upright growth. On the other hand, the Northern Spy and Ingram are very upright and should be headed back to make them spread out.

Making the Cut. Use a sharp knife and make a smooth, slightly slanting cut. When pruning, do not leave a snag, but cut as closely as possible without injuring the trunk or limb. In cutting back, cut to a bud or a branch which points in direction desired. Any large wounds should be painted with 
pure white lead paint, mixed with pure raw linseed oil. This will keep out all disease until the wound is healed.

Pruning Apple. The one-year apple tree usually comes from the nursery as a single whip. Head back to a height of eighteen to twenty-four inches, depending on height of head desired. The cut should be made slightly sloping and just above a strong bud. During the following season pinch off all buds except those selected for forming the head -four to six buds should be left. These should be on the upper twelve inches and equally distributed around the trunk so that no weak crotches will be formed. The second spring, before growth starts, head back the branches one-third to one-half of the previous season's growth. During the summer, laterals (side shoots) will grow on the main branches. Select several of these laterals on each branch and pinch back the others, leaving stubs two or three inches long. These stubs will develop into fruit spurs, and will bear fruit along the main branches, thus allowing the tree to carry a heavier crop.

This same general system can be followed for the first four or five yearscutting back each year a third to a half of the previous season's growth. At the end of this time the tree will be properly trained, and future pruning will be greatly simplified. Many more side shoots than are needed will grow out each year. Always select the ones which are strongest and which would grow away from the middle of the tree, so as to make it spread, cutting back all other shoots to short stubs two or three inches long. Do not let the head of your tree become too dense.

In pruning two-year apple, choose four to six branches and remove all others. Head back these branches to six to twelve inches, making the cut just above a sound bud which points in the desired direction. The later pruning is identical with that described under one-year apple.

In pruning bearing trees, remember the following points: Cut out all dead wood and water sprouts; where two limbs interfere, remove one of them; keep the center of the tree thinned out to admit air and sunlight; head in the terminal growth and keep the head low; prune every year.

Pruning Pear. The remarks under apple pruning will apply in a general way to the pear. The open or vase-shaped tree is preferable for the pear, because there is less danger from blight. If pear blight attacks an open-headed tree, only one branch is affected, but if it attacks a tree of the single-leader type, the whole tree becomes affected. Avoid

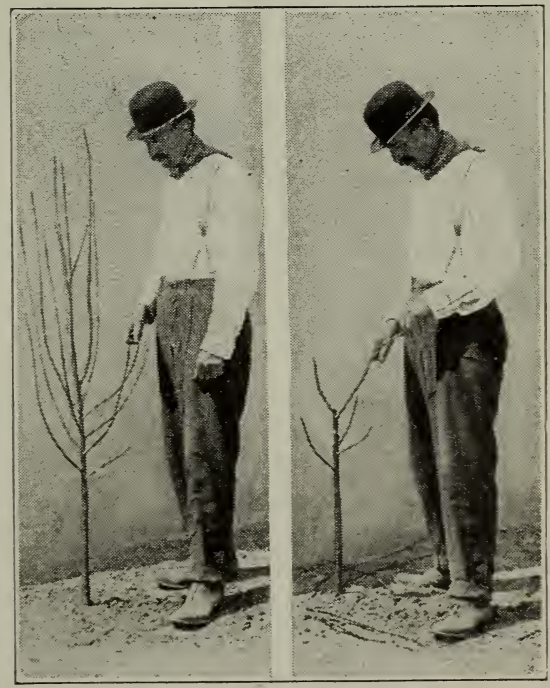

Pruning Two-Year Apple.

Prune tres to open head. End buds point outwar 1 -producing a spreading tree. 


\section{Stark Orchard a n d S p r a y B o o k}

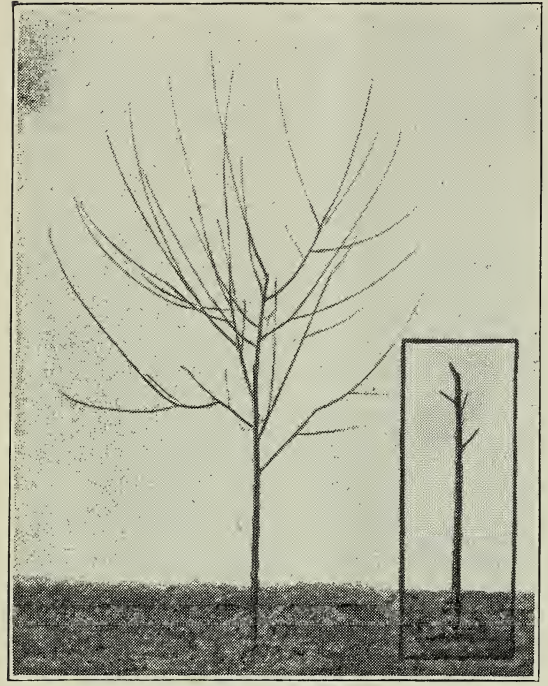

Pruning Peach.

Remove all branches, except those selected for head, which prune back to two buds.

heavy pruning of the pear, for this will cause quick, succulent growth, and make the tree more subject to blight. If the pruning causes an excessive number of water sprouts to form, they should be thinned out in the summer. The young trees of certain varieties tend to drop their fruit after it is "set." Severe winter pruning will greatly counteract this tendency.

Dwarf pear are generally pruned to the main leader (pyramidal) type.

Pruning Peach. The one-year peach tree is the only satisfactory age of tree to plant. Prune to the open-headed tree. Remove the leader, heading in to eighteen to twenty-four inches, and choose three to six branches for the framework of the tree, removing all other branches. Cut back these branches to stubs with one or two strong buds. The peach is a vigorous grower, and should be pruned severely. Head in heavily for the first three or four years, removing about one-half of the previous season's growth. After several years of this severe pruning, the result will be a shapely, low-headed tree. Prune every year and keep the head well open, allowing the sun and air to enter. This will give the fruit better color and lessen the amount of brown rot. Remember that the fruit is borne on the previous season's growth, and if allowed to go unpruned for several years the bearing wood gets too high above ground. This fruiting habit necessitates a yearly heading in of the upright branches to make the trees spread out. Thinning of fruit is also accomplished by pruning. The best time for pruning the peach is in the early spring before the buds swell.

The method of pruning the apricot is essentially the same as the peach, but should not be so severe.

Pruning Plum. Plum pruning is similar to that of peach. The different types of plum vary in their vigor of growth. The aim should be to produce good, strong branches and keep the tree in a vigorous growing condition. Keep heads thinned out. Some varieties of plums are vigorous growers and need heading back every season.

Pruning Cherry. Very little pruning is required for sour cherries. At planting time, remove broken limbs, but do not head in the branches. Keep dead wood cut out of the trees. Sweet cherry grows upright, and moderate heading back will be necessary to keep the head low.

Pruning Grape. Grapevines are vigorous growers, and must be pruned heavily every year. $\Lambda$ fter planting, cut back each cane to two buds. For the first two years vines can be tied up to a 


\section{Stark Orchard a n d S p r a y B o o k}

temporary stake, but at beginning of third year, train on trellis. When growing vines on an arbor, remove all canes except one which should be trained over the arbor, pinching back occasionally to cause branching.

There are many systems of pruning used in commercial vineyards. The following is one used largely in eastern grape-growing sections: After the young vine has grown a year, cut off in the spring all shoots except one. Tie this firmly to a stake and head back to four feet. The following season, ailow four canes to grow-two of them at a height of two feet, and the other two at a height of four feet above the ground. The third spring construct the trellis, which should consist of two strong wires fastened to posts-one wire two feet high and the other four feet high. Double brace the posts at each end of row. Tie the upper two canes to the top wire, one cane running each way along the wire, and do the same with the lower two canes on the bottom wire. The young growth of that summer will hang down and will bear fruit that season. The following spring (fourth season) cut off on each of the four main branches all of the wood back to the young cane nearest the main stalk. (Point $A$ in diagram below.) After pruning, there will

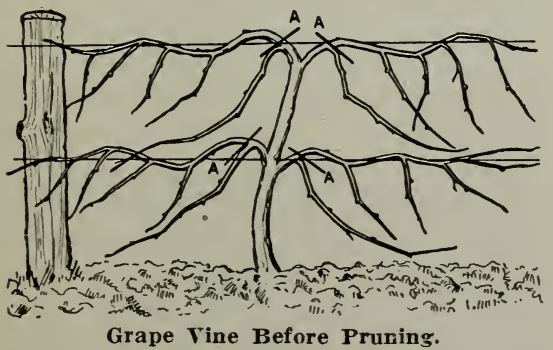

As the vine should appear after the fourth season, make cut at point $A$. be a main stalk and four one-year-old branches-two for the top wire, and two for the bottom wire. Tie up the same way as the previous season. This method of pruning should be followed each year.

Currant. The best fruit is borne un the one-year wood. If allowed to go unpruned the plants will become unproductive and the fruit will be small. After the cane has borne about three crops it should be removed. Allow several young shoots to grow each year, so they can replace the old canes. In the spring, make a judicious thinning out of old wood and superfluous young wood.

Gooseberry. Pruning is similar to the currant. Requires little pruning for the first few years, except moderate heading in of vigorous shoots in order to encourage the growth of fruit spurs. The gooseberry tends to become a dense, tangled bush and all the old weak wood should be cut out.

Black Raspberry. After the fruit has been picked remove the old canes, as each cane bears only one crop of fruit. Also if the young canes are too thick, thin out the weaker ones. The young shoots require summer pinching when about $1 \frac{1}{2}$ feet high. Pinching out the young tips will force them to branch. In

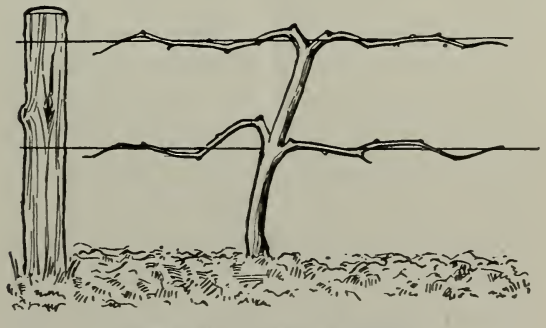

\section{Grape Vine After Pruning.}

All wood has been removed except the four young shoots closest to the stalk. 


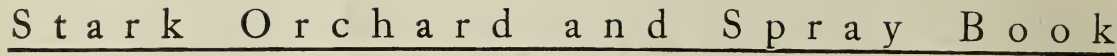

the spring, before growth starts, cut back the canes to a height of two or three feet.

Purple varieties require same treatment as the black raspberry.

Red Raspberry. Red raspberry is pruned like the black raspberry, except that the young shoots should not be pinched back during their first season of growth. The canes of the red raspberry do not come from a single crown, but grow and spread from roots.

Blackberry. Like the red raspberry, the blackberry grows and spreads from the roots. It is pruned in the same way as the black raspberry, the young shoots being pinched back during their first summer's growth.

Roses. Roses should be pruned heavily in early spring before growth starts. Slow growing plants should be pruned severely; vigorous plants only moderately. Roses (which bloom during a long season) should have the blossoms removed just as soon as the petals fall. This will make their bloom larger and more frequent.

The hardier varieties of roses can be planted in the fall, tender ones in the spring. Roses thrive best in loose, rich soil. A coating of well-rotted manure applied to the ground and well worked in is very beneficial. Plant roses two to two and one-half feet apart, depending on the vigor of the plant. The soil should be in a moist condition when planting. Press dirt firmly about roots. If planted in fall, cut back top to about twelve inches, and mound up loose dirt around plantcovering over the top with straw. In spring rake away the straw and dirt; then cut kack, leaving three or four sound buds on each cane.
Shade Trees, Shrubs, Etc. Keep the dead wood cut out of the shade trees, and paint any large wounds. Generally, shade trees will do best if allowed to grow naturally. Shrubs should be headed in for the first two or three years after planting in order to get a dense, stocky growth, but afterwards should be allowed to grow naturally. Keep all dead wood cut out.

Hedge Pruning. Immediately after the privet hedge is planted out, it should be cut back to within six inches of the ground.

Do not commence pruning the hedge until it is one or one and one-half feet high. Every time the hedge is trimmed, which should be about every two weeks, the new growth at time of trimming should be cut back to within two inches of the last pruning i. e., leave two inches growth every time.

Privet should not be trimmed after September 1st. All growth after that date should be allowed to remain throughout the winter.

Japanese Barberry can be trimmed as often as two weeks or it can be allowed to make its natural growth, which will be low and spreading. If the latter plan is followed it will require very little, if any, pruning.

Spirea Van Houttei should be kept pruned in for the first two years in order to make a dense growth. After that, do not head in branches-allow them to droop over as that is the nature of this plant.

\section{Renovating Old Orchards}

Old trees which are badly affected with diseases and insects or which seem to be in a dying condition, should probably be cut out and burned. Also, trees which have been allowed to form 


\section{$\underline{\mathrm{S} \text { a r k Orchard a n d S p r a y B o o k }}$}

a head at an extreme height from the ground and which have long, naked branches with side limbs can probably not be renewed satisfactorily.

However, trees which have been headed moderately low and whose lower branches are in fairly good condition can probably be successfully renewed. Renewal is a process of heading in and pruning down. The aim is to cause a spreading out of the lateral branches so as to $r$ ake a low-headed and spreading tree. The best time to do this severe pruning is on mild days during late winter. The first season head in severely the topmost branches, leaving all healthy, spreading side branches. The head of the tree will probably be very dense. Judicious thinning out of all excessive branches should be made so as to open up the head and allow the sun and air to get into the middle of the tree. However, some young wood should be left to produce the following season's growth.

The following season side branches will throw out new shoots and the trees should begin to present a uniform low head. The next pruning season-in late winter-horizontal branches can be slightly headed in.

The above pruning will cause the old branches to throw out a number of young shoots and these should be kept thinned out, leaving only enough to furnish sufficient bearing wood. The shoots that are left should be clipped back one-third of their length so as to cause them to make lateral growth instead of growing upright.

Immediately after trees have received a severe heading in and thinning out of dense tops, spray them thoroughly with commercial lime-sulphur (1 part to 8 parts of water). This spraying can be applied during mild days of late win- ter or during early spring before buds start. The thinning out and heading in of the trees leaves them in excellent condition for a general clean-up spray to effectually control insects and diseases.

In cutting large branches the following plan should be used: Saw first on the under side part way through the branches, then saw from the upper side to meet the under cut. By following this plan, the branch will break off without splitting the main part. After the branches have been removed and the wounds have had a chance to dry somewhat, paint them with pure white of lead and raw linseed oil.

The renewal of orchards will be of little benefit unless it is followed up by judicious annual pruning-thinning out and heading in the growth.

Systematic spraying of the orchards (note directions latter part of this book) should be made each year in order to control insects and diseases which attack, the trees.

The orchard may be in need of plant foods, in such case a good application of stable manure will be beneficial.

Dynamiting old trees which are making a slow, unsatisfactory growth and not producing fruit, is beneficial. Note page 17 for use of dynamite on old trees. Do not put the dynamite directly under the tree, but at a distance of seven to fifteen feet, using about four shots to each tree.

Important. Do not make the mistake of trying to renew old orchards which are too far gone. It will merely be a waste of time and labor. It takes only a short time to grow a young orchard of up-to-date, profitable varieties. Many of the best sorts of apple bear at exceptionally early age-three to six years. Peach bear much younger. 


\section{Stark Orchard and Spray Book}

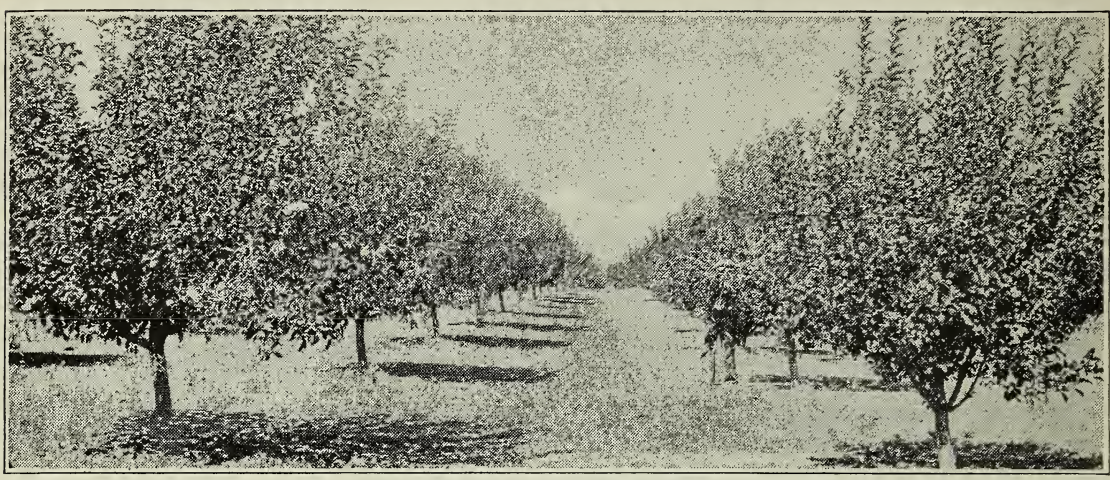

Pioneer Stark Denver Orchards.

Value of intensive cultivation and dust mulch were demonstrated in this orchard, referring to which U. S. Government authorities said: "This lesson will be worth millicns to the country."

\section{Orchard Cultivation}

Practical experience has shown that orchards should be cultivated. Tillage keeps the soil in good, loose condition and increases its water-holding capacity. Frequent shallow cultivations keep the top two or three inches of soil loosenedmaintaining a dust mulch which acts like a blanket in preventing the evaporation of the soil moisture. The plant foods are made available by cultivation, and manure gives better results when used on tilled land.

Young orchards, as well as old orchards, need cultivation. In a young orchard, crops, such as currants, gooseberries, etc., may be grown between the rows, but never closer to the tree than five feet. The cultivation of the crop will generally be sufficient for the trees. Never grow such crops as hay or grain. They rob the soil of large quantities of moisture and plant food without giving anything in return. Cover crops, such as clover, vetch, cowpeas, etc., are very desirable to grow between tree rows. (For details on Cover Crops, see page 25.)
Partial Cultivation. Trees may be set in broken strips six feet wide, balance of space between the rows left in sod. Trees may be cultivated in this strip for a year or two and gradually widened just as the trees grow. This plan is applicable for plantings where washing is serious.

The number of cultivations during a season depends somewhat on local conditions of soil, climate, age of trees, etc. Young, vigorous-growing trees should not be cultivated or irrigated as late in the season as bearing trees, because they will grow late and the immature growth will be very liable to winter injury.

$\Lambda$ good plan of cultivation used by many successful orchardists is as follows: Plow in the spring (not deep enough to injure the roots) as soon as the soil is in good condition. Turn the soil toward the trees the first year and away from them the next year. Various instruments can be used for later cultivations, but the aim should be to maintain a dust mulch. Cultivate after every rain as soon as possible. If the crust is not broken, a large loss of 


\section{Stark Orchard and Spray Book}

moisture will result. Cultivate the orchard every week or ten days, depending on conditions. Stop cultivation on young trees latter part of July, or earlier, in some sections. This will give the new growth time to ripen before the severe weather. Older trees may be cultivated later. At the last cultivation, sow cover crop, and a good ground cover will result before winter. The next spring plow under the cover crop. Clover may remain on the ground for a year and be plowed under the following spring.

Tools for Cultivation. Turning plow, cutaway or disc harrow, spike tooth, or regular orchard harrow with extension. Short single trees, especially made, should: be used on these implements and wrapped at the ends with burlap to prevent barking trees.

\section{Cover Crops}

Often soils get "burnt out," due to a lack of humus in the soil (see page 7.) Humus is partly decomposed organic matter. The way to add humus to the soil is to plow under a heavy coat of manure or cover crops. The maintenance of humus in orchards is one of the biggest problems confronting the fruit grower. Cover crops solve the problem very effective'y. The cover crop (also called green manure) is sown in the middle of summer, or early fall, and grows until the following spring, when it is plowed under. Some of the advantages of a cover crop are as follows: Checks the growth of the tree and allows young wood to mature before winter; prevents winter washing of the soil with its loss of soil fertility; makes the land easier to cultivate; prevents root injury from excessive freezing; tends to delay growth of the young trees in spring until after the killing frosts; and, most important of all, it adds plant foods to the soil.

There are two classes of cover crops; first, leguminous, those which take the free nitrogen from the air; second, nonleguminous, those which can use only the nitrogen already in the soil.

Leguminous cover crops include the clovers, cowpeas, vetch, soy beans, field peas, etc. The nitrogen is taken from the air by bacteria which live on the roots. These bacteria form on the roots little knots or nodules which consist mainly of nitrogen compounds. This class of cover crops is excellent for building up poor land. The cowpea is one of the best for the Central and Southern States, but is not satisfactory in the North. The clovers are excellent, and thrive orer a large territory. Hairy vetch and soy beans are among the best for the Central and Northern States.

Non-leguminous cover crops include rye, buckwheat, barley, cow horn turnips, rape, etc. These plants do not use the free nitrogen of the air, hence do not enrich the soil as much as the leguminous crops. In certain cases it is desirable not to add too much nitrogen for

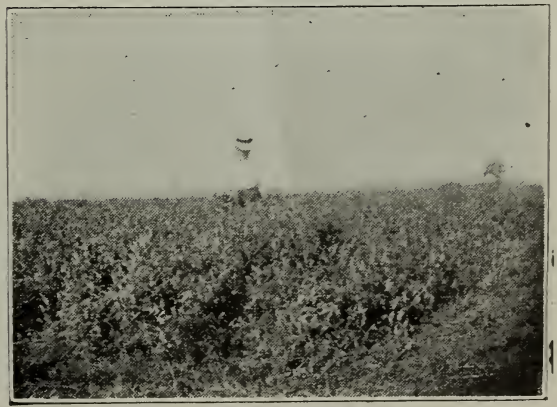

Hairy Vetch.

One of the best orchard cover crops-hardy in North. Note the thrifty, dense growth. 


\section{Stark Orchard a n d S p r a y B o o k}

fear the growth of the trees will be too vigorous. This is especially true of pear trees where the vigorous, succulent growth is susceptible to pear blight. Buckwheat loosens up the soil well, and grows on very poor land, but kills down in winter. Rye thrives well on nearly all soils and is hardy. It should be plowed under in the spring before it grows too rank.

Combinations of different crops will give the best results. Some good combinations are: 1, hairy vetch and rye; 2, buckwheat and clover; 3, rye and buckwheat (when large amounts of nitrogen are not desired).

\section{Amount to Use Per Acre.}

Mammoth Clover...........15 to $20 \mathrm{lbs}$. Crimson Clover............... Red Clover................ Cowpeas .................

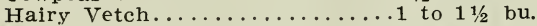
Soy Beans............... $1 / 2$ to $1 \mathrm{bu}$. Buckwheat ............... bu. Rye ..................11/ to 2 bu. Canada Field Peas........... $1 \frac{1 / 2}{\text { bu. }}$ Barley ..................... Turnips ............... lbs.

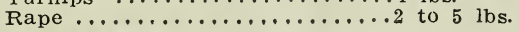

\section{Fertilizers}

During the last few years there has been much discussion on the subject of commercial fertilizers. Under certain circumstances, high grade fertilizers are no doubt of great benefit to orchards, but they have often been used when full value was not received.

We quote Prof. L. L. Van Slyke, of the N. Y. Agr. Exp. Station:

"Recent experiments have shown that on fertile soils, especíally of the heavier types. the use of fertilizers, continued for years even in large amounts, does not show any appreciable effects, whether in the case of old orchards or young ones, provided cover crops, including leguminous, are used, and up-to-date methous of tillage practiced. As a general rule, as $1 \mathrm{cng}$ as trees continue to make satisfactory growth of wood and produce average crops of good, well colored fruit, no commercial fertilizer need be supplied."

The fertilizer needs must be determined largely by the orchardist. Try different fertilizers on a small scale, and in this way you can correctly determine

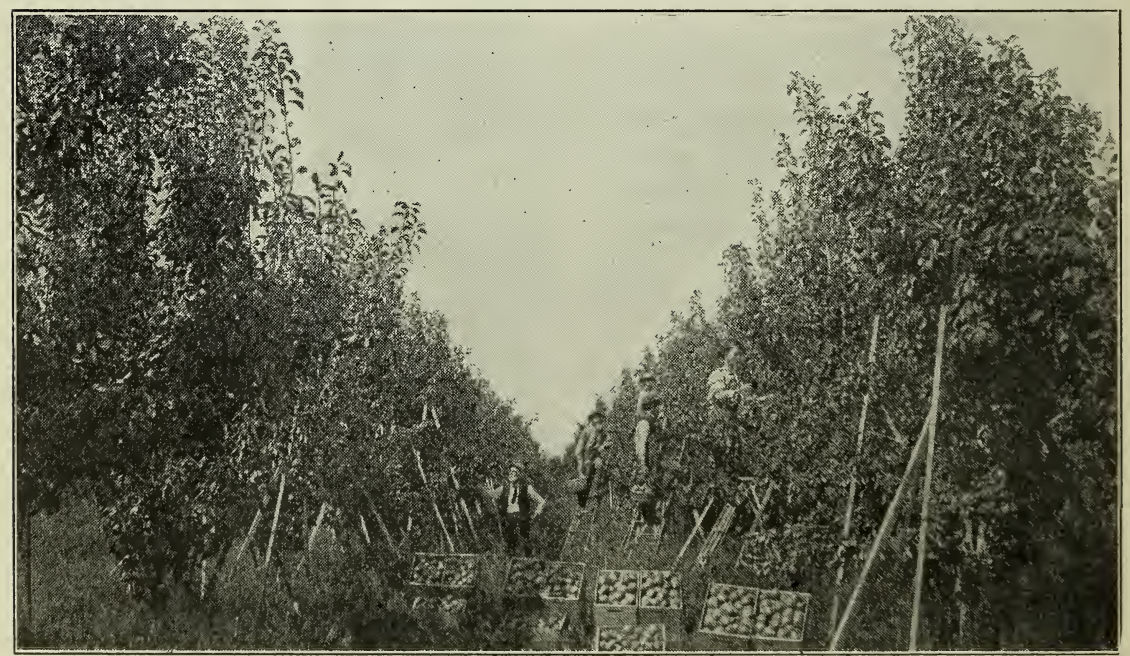

Picking Pears.

Note the picking baskets. Fruit is put in boxes and hauled to packing house. Pick pears while still perfectly solid and allow to ripen in a cool storage or ship at once. 
your fertilizer needs. The high grade fertilizers are the cheapest, considering the amount of real plant food they contain.

There are ten elements essential to plant growth, and in most soils they are present in sufficient quantities for the needs of the tree. However, the three elements which may possibly be lacking are nitrogen, phosphate, and potash.

Nitrogen may be supplied by cover crops, manure, dried blood, nitrate of soda, etc. The cheapest and most satisfactory method to supply nitrogen is to grow leguminous cover crops.

Phosphate can be furnished in the form of acid phosphate, bone meal, ground phosphate rock, etc.

Potash may be applied in the form of wood ashes (which also contain a large percent of lime).

A complete fertilizer contains all three elements. The three figures, by which they are called, refer to the percentages of the three elements. For example, in a 4-9-10 guarantee, the 4 refers to $4 \%$ nitrogen, the 9 to $9 \%$ phosphate, and the 10 to $10 \%$ potash.

Occasional applications of finely ground lime will "sweeten" acid soils and will be very beneficial to the orchard.

The value of a fertilizer depends on the pounds of actual plant food and the grade of the material In applying fertilizer be sure that it is well worked into the soil by cultivation.

We quote Prof. J. P. Stewart, Pennsylvania State College of Agriculture, Bulletin 121:

"In general, the characteristics of an orchard that is certainly in need of a fertilizer are those of starvation. Foliage is sparse and pale in such orchards and the annual growth stops early and averages short. In most young orchards and any orchard that is growing and fruiting well, and retaining its foliage until late in the season, fertilization is much less likely to show a profit.

"Time of Application. Distinct harm may result from application ot nitrates about fruit setting time. We found therefore that the nitrates should be applied not earlier than petal-fall in apples and not later than the middle of July. When the crop is light, much smaller applications are required than in the full years.

In case of mineral ingredients with their slower acticn, the time of application is less important.

"Scatter the fertilizer or manure broadcast cver the surface of the ground, taking care not to get it too close to the tree trunk and extending applications well out under the spread of the branches. The fertilization may be left on the surface to be washed in by the rains or may be harrowed or lightly plowed under the soil. Importart results, therefore, should not be expected before the following season at the earliest and they may not appear in apple until considerably later and prove of considerable value."

"It seems that most orchard soils are already supplied with sufficient potash in avail. able forms and the chief shortages occur in the nitrogen and phosphate.

"Plant food action of manure is practically identical with that of a commercial fertilizer-rich in nitrogen and phosphate. Manure also has some additional value as a result from its mulching effect.

"In general the same influences that hare materially increased the yield have also increased the growth. In other words, our best growing plats have, as a rule, been our best fruiting plats. On suund, healthy trees, this will generally be the case unless either occurs to an abnormal extent.

"If one wishes to answer how to fertilize his own orchard he can do so by following the rlan outlined below. It is the only way by which one can really become acquainted with the needs of his orchard:

1. Check (unfertilized).

2. Nitrate, $2 \frac{1 / 2}{2}$ lbs.; dried blood, $3 \frac{1}{2}$ lbs.; acid phosphate, 10 los.

3. Nitrate, $2 \frac{1 / 2}{2}$ lks.; cried blood, $3 \frac{1 ; 2}{1}$ lbs.; potash, 2 lbs.

4. Acid phosphate, 10 lbs.; potash, 2 lbs.

5. C'heck.

6. Nitratc, $21 / 2$ ibs.; dried blood, $31 / 2$ lbs.; acid phosphate, 10 lbs.; potash, 2 lbs.

7. Same as 6 , plus lime, 12 to 25 lbs.

$S$ lianure, 400 los.

9. Check.

The materials are indicated here in amounts per bearing tree, instead of per aere (page 26), and the same proportionate leductions should be made for younger trees. In other words, if only a third of the ground is to be covered, then only about a third of these amounts should be used, if the rate of application is to be kept within proper bounds. This test should be located in a typical part of the orchard, and should include not less than 5 average trees of the same variety and age, in each plat. 


\section{Stark Orch a r d a n d S p r a y B o o k}

\section{Irrigation}

"In districts with less than 20 inches of rainfall, irrigaticn can become a great help, and in many cases is a necessity. In irrigation, the problem is to see how little water to use instearl of how much. Irrigation must go hand in hand with cultivation. Under most conditions about two irrigations during the growing seascn are ample where the ground is thoroughly moistened, and followed by intensive cultivation. Avoid using large amounts of water near the time of harvesting."-Prof. C. I. Lewis, Ore. Agri. Exp. Sta.

\section{Orchard Heating}

Frosts do their main damage in the spring at blooming time and sometimes cause serious losses. Frost is worse in valleys and pockets than on slopes where there is sufficient air drainage. Therefore, in selecting the site for your orchard choose gently sloping or rolling land where the air drainage will be good. On still, clear, cold nights there is the greatest danger from frost.

Orchard heating has been mainly practiced in the western fruit-growing regions. In sections where the fruit crop is often destroyed by late frost, the subject of orchard heating should be carefully investigated. The only important objection to orchard heating is the original cost of installing the system.

Orchard Heaters are sheet iron receptacles, which usually burn coal or oil. However, the majority of growers, who heat their orchards, have adopted the use of oil as the most satisfactory fuel.

Does Orchard Heating Pay? If injury from spring frosts is a limiting factor in determining whether there will be a full crop or failure, heating does pay. In many localities destruction of the crop by spring frosts is not frequent. Under these conditions, the extra expense probably would not be advisable.
However, before installing a system of orchard heaters every operation of orchard management should be cared for in the best possible manner so that the crop you do save will be strictly No. 1 fruit, which will command a high price. It would not pay you to heat an orchard that had not been carefully pruned, sprayed and kept in a healthy growing condition.

In apple and peach orchards it is not safe to use less than 60 or 70 of the large type of heaters per acre. If you are going to heat your orchard, do it thoroughly. Have everything in readiness for immediate action as frosts usually come on short notice.

\section{Thinning Fruit}

Thinning is one of the most profitable orchard operations. Practical orchardists have given thinning a thorough trial, and have found it pays-decidedly. The annual pruning helps to thin the fruit. Many growers prefer to delay the hand thinning until after the socalled "June drop."

Some fruit growers object to the extra expense of thinning. However, it does not cost much more to pick the surplus fruit early in the season than in October at picking time. The extra profit from well thinned fruit will easily overcome the added expense.

Thinning improves the size and color of the fruit, producing a greatly increased percentage of No. 1 fruit; also, thinning tends to eliminate the alternate bearing habit of trees. Some trees bear lieavily one year and the following year do not bear at all. By thinning the crop one year the tree can recover and be in condition to bear a crop the following year. 
First, remove all wormy or defective fruit, then thin out the clusters. Do not injure the buds or fruit spurs for they are to bear the next year's crop. Young trees should not be allowed to bear heavy crops because the shock of overcropping will give the tree a setback. No specific rule can be given for thinning the various fruits. Some varieties require more thinning than others.

Thinning peaches is necessary to produce first-class fruit. Four to six inches between the fruit is the distance we advise. In thinning apples, shears may be used instead of removing by hand.

\section{Pollination}

Certain varieties, when grown in isolated blocks, will not bear crops. This is usually due to the blossoms being self-sterile-that is, the pollen, which is the yellow dust in the blossom, will not pollinate its own blossom. If the blossom is not pollinated the fruit will not "set."

A self-fertile variety is one the pollen of which will pollinate its own blossom. Self-sterility is a chalacteristic of certain varieties, but it varies in different sections and under different conditions. A variety may be self-sterile in the North, but in the South it may be selffertile. This is true of Keiffer pear.

It has been provien that cross-pollination of one variety with another gives better resilts than when the blossom is pollinated by its own pollen. Cross-pollination makes the fruit larger, more uniform, and causes a larger crop to set. The fact that a variety is selfsterile does not mean that its pollen cannot fertilize a blossom of another variety. Two self-sterile varieties will usually pollinate each other if they bloom together. Insects, especially bees, cause

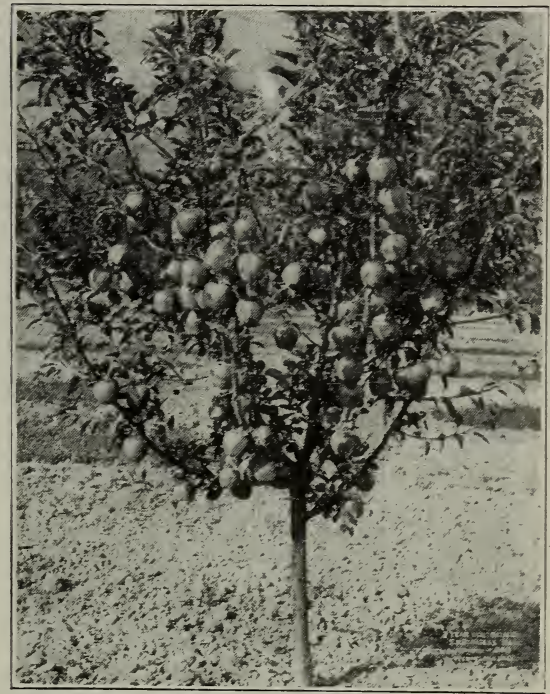

Well Thinned Tree.

A three-year-old Stark Delicious apple treeshowing strong growth and early bearing.

most of the cross-pollination when they visit the blossoms. The pollen gets on their legs, and in this way is carried from blossom to blossom. Never destroy bees, and in large orchards keep a few hives in the orchard.

Never plant solid blocks of any one variety, but set out several varieties in your orchard so that cross-pollination will be certain. Do not plant more than four rows of a single variety together, then the same number of rows of another variety. By mixing three or four varieties in this way, pollination will be practically assured.

\section{Reasons for Not Bearing}

Poor pollination is not the only reason some orchards fail to bear. Buds may be injured by frosts although in outward appearance they seem perfect.

Trees which arz making too thrifty a growth delay fruiting. A moderate 


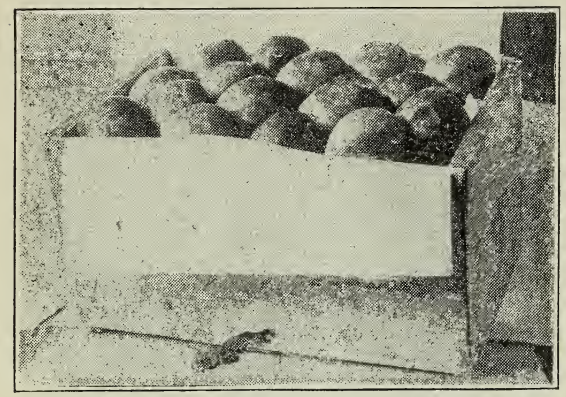

Sixty-four Apples to the Bushel.

A four-tier box of Stark Delicious-the biggest money-making apple.

summer pruning, as described on page 17, will throw them into bearing.

Due to continued lack of care and lack of plant food, a tree may be so weakened that it cannot "set" a crop. The best remedy, in such a case, is to plow the orchard and grow cover crops, turning under the following spring, or apply a heavy coating of manure. Several charges of dynamite exploded at intervals about the tree will give the tree increased vigor. (For details, see pages 15 and 17.)

\section{Picking and Packing}

Picking fruit must be done carefuliy and at the right time, because keeping qualities are largely dependent upon the method and time of picking. Just the proper state of maturity at which fruit should arrive before picking time is a matter of great importance. When fruit is allowed to remain on trees too long it becomes over-ripe and will not hold up well in shipment or storage. Sometimes varieties of apples are condemned by the grower when it is often the fault of not picking soon enough. Red apples should be picked when they reach high color and maximum size. In the case of yellow apples the maturity is judged by the color of the seeds-when they turn light brown and before they become dark around the edges indicates the proper time for picking.

Jonathan, Grimes Golden, and Stark King David should be picked earlier than most winter apples. If picked at the proper time, they will keep well in storage.

The following varieties should be picked later than Jonathan or Grimes Golden, that is, about mid-picking season: Rome Beauty, Stark Delicious, Senator, etc.

The varieties that can be picked the latter part of the picking season are Stayman, Ingram, Champion, York Imperial, Black Ben, Paragon, Winesap, Mammoth Black Twig, etc.

One indication of the proper time to pick most kinds of fruit is to lift them up gently and give a slight twist. If the fruit comes off easily it is ready to pick.

The ideal method is to pick, pack, and ship the fruit the same day if possible. In picking use a picking bag or a good picking basket. One of the best types of basket is the swing-bail basket.

Ladders. High headed trees are much more difficult and more expensive to pick than low headed trees. In the latter case, a large percentage of the crop can generally be picked from the ground. There are a number of types of ladders for picking fruit. Some of the main points that should be considered in getting ladders are as follows: The ladder should be made of strong material but of fairly light weight, and should have a broad base which makes it staple.

Caution the pickers not to break off the fruit spur as they are to bear fruit the following year. 


\section{$\underline{\mathrm{S}} \mathrm{tark} \mathrm{Orchard}$ a nd Spra y B o o k}

The picker should put the fruit in the basket with his hand-do not drop the fruit. Tell the pickers that all fruit should be handled as carefully as eggs if the best keeping results are to be secured. Never bruise the fruit with the thumb or break the stems. Under no condition should the fruit ever remain in piles in the orchard.

Apples are hauled to the packing houses in boxes where they are emptied on sorting tables. The modern sorting table generally has a canvass bottom to prevent bruising of the fruit.

Pears should be picked while still hard and just as soon as the seeds turn brown. If they are to be used at home put them in a cool dark place to ripen. In fact it is absolutely necessary to pick many varieties of pears before they become mellow on the tree, otherwise they will rot at the core. If the pears are to be shipped, pick and ship them immediately. It is a good plan to wrap pears separately in paper.

Peaches for shipping should be picked when matured (maximum size and color)_but still perfectly soiid.

Apples are packed either in boxes or barrels. The box pack is rapidly coming into favor but only the best grades should be packed in boxes. If fruit is shipped to certain markets it is advisable to line the box and wrap each apple separately with paper. No matter whether you pack in boxes or barrels, be sure that your fruit is careful'y graded. After the fruit is packed, see that it is shipped at once, or stored in a cool storage where it will be protected from freezing.

\section{Marketing the Crop}

If the grower is to get the best returns from his crop, he must pay partic- ular attention to the question of marketing. In the first place, the fruit should be carefully graded and packed so a reputation will be worked up and the buyers will have confidence in the grower's pack. Second, plant the high quality varieties. Consumers have been educated to high quality and it is useless to attempt to make them pay good prices for inferior varieties.

"If you have a nice lot of Jonathans, Stark Delicious, Grimes, or other fancy varieties, do not sell them separate from your Ben Davis, or slower-selling apples. Of course, sometimes a buyer may offer such a good price for the fancy varieties that it will pay to sell them and dispose of the balance some other way."-A. P. Boles, Sec. of IMo. State Board of Horticulture.

To sell a crop to best advantage, it is necessary to start early. In fact, for best results, the grower should have his fruit sold before he starts picking so he can grade and pack intelligently-meeting the requirements of his contract. High grade apples should be free from insect or disease injury; should neither be bruísed nor rotted, and should be

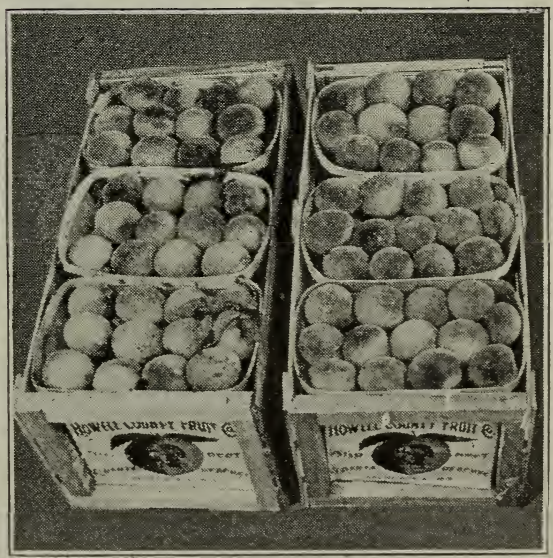

Peaches Properly Packed for Shipment. Shipping quality is extremely important. Stark Early Elberta is an ideal shipper. 
above a certain specified size. This minimum size varies with different varieties. For instance, smaller sorts, such as Jonathan or Winesap, have a smaller minimum size than larger varieties, such as Stark Delicious, Black Ben, and Stayman Winesap. It will not pay to put low-grade apples in storage, but if possible they should be handled so as to cut out cost.

The up-to-date, successful fruit-grower keeps in touch with the fruit market and he will start very early in the season to market his crop so that when it is time to pick, he will know exactly where he is going to dispose of his fruit. The grower should tell the fruit buyer all about his crop-different varieties, the probable size and amounts. It is also advisable to send samples.

In order to keep in touch with market conditions, it is a good plan to subscribe to one of the fruit market papers.

Our Special Service Department has lists of buyers of fruit, and will be glad to furnish them to orchardists free of charge. We will help to put you in touch with buyers so that you can dispose of your fruit to best advantage.

"I want to especially thank Stark Bros. for suggesting my name to prospective buyers-I appreciate that. Have sold my entire crop."-C. M. Fette, Marion Co., Mo.

The selling of the crop should be handled in a business-like way-the grower should make a contract with the buver and let all terms be fully understood. Some of the points which should be contained in the contract are the following:

First, is the fruit to be paid for by the barrel, box, hundred pounds or lump sum and what price? Second, what constitues a No. 1 grade or No. 2 grade? Third, who is to do the picking and packing and when? Fourth, who is to haul empty barrels to the orchard and packed barrels to the station?

Method of Selling. There are a number of ways to sell the fruit. For a progressive fruit-grower, who knows his business and understands the methods of picking, packing, etc., the following is one of the best contracts: selling by the barrel or box, f. o. b. loading station; cash to be paid for the fruit.

Another method is to sell the fruit by the barrel, the buyer to do the packing; one price to be made for both No. 1 and No. 2 grades. In this way the grower will be protected. If the contract reads that the fruit is sold on the table, the grower does all the picking and hauling, the buyer furnishing the barrels or boxes, doing the sorting, grading, and packing. The cost of buying empty barrels, picking, packing, and doing all the hauling of the fruit, amounts to about $\$ 1.00$, more or less.

Some growers sell the crop for a lump sum, fruit to be picked and handled by the buyer; but, as a general proposition, this plan is not satisfactory. A progressive orchardist, by keeping in touch with the market, should be able to realize greater profits by handling his own fruit. If the buyer is to pick the fruit, it will probably result in damage to the trees by breaking the limbs, fruit spurs, etc.

Some growers consign their fruit, but as a whole, one of the other methods outlined above is generally more satisfactory for the small grower.

Many growers who pack their fruit well and who are in touch with market conditions, hold their fruit in cold storage until they can take advantage of the high prices late in the season. However, it should be understood that only strictly first class fruit should be put in cold storage. 


\section{Book II.}

\section{Spraying Fruit Trees}

\section{Foreword}

In the preparation of this book for the orchardists of America we have embodied not only our own personal experience, not only the extensive tests of our own orchard experts, but we have drawn on the leading horticultural and spray authorities in all sections. In short, this book is written to meet the varying conditions in all different localities.

Especially are we indebted to the following for their valuable suggestions and advice in preparing this book.

J. C. Whitten, Dean of Horticulture, Missouri State University

J. P. Stewart, Professor of Pomology, Pennsylvania State College of Agriculture Donald Reddick, Professor of Plant Pathology, Cornell Agr. Exp. Station Glen. W. Herrick, Professor of Economic Entomology, Cornell Agr. Exp. Station E. H. Favor, Editor, Fruit-Grower and Farmer, St. Joseph, Missouri

Important. Spraying is much more simple than is ordinarily believed. Efficient spraying can be done economica'ly. Remember that the benefits are many and far reaching. Spraying your trees results in larger and better fruit. Big prices and enormous profits are received by the progressive grower who sprays his trees every year, keeping then in a healthy, growing condition, thus enabling them to produce good, annual crops of No. One fruit.

Fruit tree enemies (insects and diseases) must be controlled, and spraying is the best way to do this. Spraying is no longer an experiment, but it has become as importart as pruning, cultivating, etc.

Spraying Pays. It keeps the tree in a healthy, vigorous condition, maintaining the leaves in good working order so they can manufacture the food for the plant and thus assure a crop for the following year. By keepinz the tree in a healthy condition it means long life for your orchard, and the trees will be in better shape to bear good, annual crops, but it is necessary to spray every year.

Losses. Annual loss, due to some of the more important insects and diseases, such as Codling Moth, Apple Scab, Brown Rot, Curculio, San Jose Scale, is appalling. It has been estimated that the loss une to the Codling Moth alone in unsprayed orchards is one-half to three-fourths of the crop. A large percentage of this loss can be prevented by thorough spraying. Another reason for spraying is because insects and diseases are now more generally distributed throughout the country than formerly. The question to be decided is: What are the most economical, most thorough methods and materials to use in order to get successful results? 
Cost of Spraying. In Bulletin 102 of Missouri Agricultural Experiment Station the following statement is made:

"It is impossible to give any accurate estimate of the cost of spraying unless the size of the trees is known. It is usually necessary to spray fcur times a year. With trees varying from twelve to eightcen years of age, growing in reasonably good soil, the cost of material will vary from nine to thirteen cents a tree for four sprayings. The cost of labor is usually ten to filteen cents per tree. The total cost, then, of the four sprayings for labor and material would range from eighteen to twenty-eight cents a tree."

\section{Essentials of Spraying}

1. Epray Thoroughly. It is necessary to coat each leaf with a fine, misty spray. Careless, inefficient spraying is worse than useless as it is an added expense and does not give satisfactory results. To properly apply the spray, good pressure is required. The pressure should be not less than 100 pounds and some nozzles should have 150 to 200 pounds pressure for the most efficient work. Coat the under and top sides of the leaves with a fine mist. It is not advisable to have spray material too thick on. the foliage, because drops form and hang on the lower edge of the leaf, thus allowing a large quantity of spray mixture to accumulate on a small portion of the leaf, which often results in the burning of the foliage.

\section{Know Why You Are Spraying.}

Study the habits and developments of the insect or disease so the spray can be applied when it will do its most efficient work. The sprays which control plant diseases are seldom of any use in combating chewing insects hence there are sprays for each. Fortunately, they can generally be mixed and applied at the same spraying.

3. In combatting fungous diseases remember that the aim is to prevent the injury and not to cure it. During rainy weather most diseases spread more rapidly than during dry weather, hence when spraying for diseases always spray before rains, not after.

4. Use fresh, good quality spray materials and prepare them carefully. Keep all poisons labeled so as to prevent accidents.

5. Never spray trees when in bloom, as the poison is liable to kill bees and injure the blossoms.

6. Spray in Time. Have your spraying outfit and your spray materials in readiness so that work can be begun on short notice. The time for spraying is at best very short, often limited to a few days. It is better to keep your trees in a healthy, growing condition by a systematic plan of spraying than to wait until they are weakened by diseases and insects.

7. Spray Every Year. No matter whẹther you have a crop or not, you should spray every year. Spraying kecps the foliage healthy, thus enabling the tree to form fruit buds which will produce the following year's crop. We can not too strongly emphasize the importance of spraying every year.

Failure to observe the above essentials has caused some orchardists to doubt the usefulness of spraying. However, careful, thorough sprayings made at the proper time will be of utmost impurtance in making fruit-growing a profitable business.

\section{Latest Developments}

Recent experiments and practical tests indicate that in most cases the use of commercial lime-sulphur in its dilute form (1 to 40) is superior and preferable to Bordeaux Mixture, which has been the standard for years for summer spray- 


\section{Stark Orchard and Spray B o o k}

ing of apples. While we give the use of Bordeaux in this book, leading authorities advoca : the dilute commercial limesulphur ( 1 to 40 ) used in connection with 2 pounds of arsenate of lead to 50 gallons of the solution. However, in the Middle West and certain portions of the Southern states where Bitter Rot and Blotch are prevalent, Bordeaux Mixture must be used for the late sprays, using the dilute commercial lime-sulphur for the early sprays.

The great objection to using Bordeaux Mixture is the injury which is sometimes caused thereby, commonly known as "Bordeaux Injury." It is believed by authorities that Bordeaux injury is most often produced at the time of the early sprays, so that the later applications of Bordeaux Mixture are not apt to cause injury to the fruit. For further data on Bordeaux injury, see page 40.

Note. The remaining portion of this book is divided into two sections as follows:

1. General descriptions of insects and of fungous diseases, followed by method of control. After each fruit is given a general outline for spraying that particular fruit.

2. Methods of making and applying the different spray materials-insecticides and fungicides (the latter for control of plant diseases). There are a!so included some helpful advice and hints for selecting spray outfits.

\section{Section I.}

\section{Classifying Tree Pests}

Orchardists have three general classes of fruit tree enemies to combat.

1. First class includes insects which are divided into two kinds as follows:

a. Chewing Insects. For example, the larva of the Codling Moth (commonly known as the Apple Worm), Curculio, Currant Worm, etc. These insects eat portions of the plant, or fruit, and they are killed by the stomach poisons (like arsenate of lead) which are sprayed on the foliage and fruit.

b. Sucking Insects, such as Plant Lice, San Jose Scale, etc. These insects have beaks which they insert into the branch or leaf and then suck the sap. To kill them, these insects must be hit by some contact spray, such as concentrated limesulphur (1 gallon to 8 gallons of water, used only when tree is dormant), Whale Oil Soap or Tobacco Extracts. See Section 2 for methods of preparing these materials.

2. The second general class of tree pests is the fungous diseases (such as Apple Scab, Brown Rot of stone fruits, Black Rot of grapes, etc.). These are controlled by fungicides such as dilute commercial lime-sulphur ( 1 gallon to 40 gallons of water), Bordeaux Mixture or self-boiled lime-sulphur.

3. The third general class of tree enemies includes the bacterial diseases (such as Fire Blight of the pear). This disease can not be controlled by spraying, but must be overcome by constant pruning and burning of the affected parts. See page 44 for control of Fire Blight.

\section{Spraying Before Bearing}

The aim in spraying young trees before they come into bearing is to keep them in a healthy, vigorous, growing condition.

All young trees should receive an application of commercial lime-sulphur, 1 gallon to 8 gallons of water, in the spring before the leaf buds swell. Later applications will only be necessary to protect the foliage of the tree from any insects or diseases that appear. 
For ary leaf-eating insects, spray with Arsenate of Lead $2 \frac{1}{2}$ pounds to 50 gallons of water. It would be well to add 3 or 4 pounds of fresh stone lime to prevent any possible burning of the leaves.

For sucking insects such as Aphis (Plant Lice), spray with Kerosene Emulsion $10 \%$, or Whale Oil Soap 1 pound to 6 gallons of water, or with Tobacco Extracts. These are contact insecticides and it is necessary to hit the insects.

In the case of young apple or pear trees, if any leaf diseases attack the foliage, spray with dilute commercial limesulphur, 1 gallon to 40 gallons of water (50 gallons for pear). The second application can be made about 3 weeks after the first. The lime-sulphur and Arsenate of Lead can be mixed and applied at the same spraying, if desired.

\section{Apple}

\section{Apple Insects}

Codling Moth. Description-Commonly called the Apple Worm. A whitish or pinkish caterpillar about one-half to three-fourths of an inch long. Adult moth appears in the spring, lays its eggs on the leaves or small apples soun after blooming time. Eggs hatch and the young caterpillars, at first only about one-sixteenth of an inch long, enter the apple, usually at the blossom end.

Herein lies the control: Arsenate of Lead must be sprayed into the calyx cup (blossom end) so that the young caterpillar will get a dose of poison as soon as it starts to enter the apple. The worms that are successful in entering the fruit attack the core, remaining in the apple about four weeks and then leaving through a hole in the side. There are often two generations, and if the first generation is not controlled by spraying, the injury from the later generation will be serious.

Control-Spray immediately after blossoms fall with Arsenate of Lead, 2 or 3 pounds to 50 gallons of water. Repeat application two or three weeks later. The first application for Codling Moth must be made when the calyx is open and extended, so that the poison can be forced into the blossom end of the young apple. (See illustration page 42.) For this reason it is necessary to use good, strong pressure (at least 150 pounds or more), and make this spray very thorough. In the Middle States, where there is generally a second brood of Codling Moth, an application can be made at the same time the Bitter Rot sprays are applied, that is, eight or nine weeks after the blossoms fall. Use $2 \frac{1}{2}$ pounds Arsenate of Lead to 50 gallons of Bordeaux Mixture. Where the first application is thorough, spraying for the second brood will not be so necessary.

San Jose Scale. Description-Can be controlled by spraying. A small, circular, grayish colored scale-insect, about the size of a pinhead. When abundant, forms incrustation on the branches. On the fruit or light colored bark, scale is surrounded by a reddish spot, thus making its identification easy.

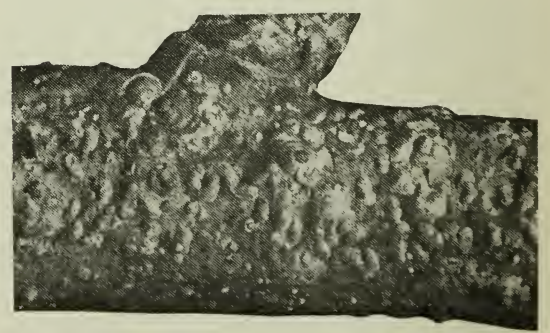

San Jose Seale.

Attacks many kinds of trees, but can be controlled by spraying. 


\section{$\underline{\mathrm{Stark} O \mathrm{O} \text { h h a d a n d S p a y B o o k }}$}

Only the young, half-grown insects are able to survive the winter and reproduce the following spring.

Control-The presence of this insect necessitates spraying. The time to spray for San Jose Scale is on a mild winter or early spring day-just before the buds begin to swell (while tree is still dormant). In case of bad attacks, another application should be made in mild days during the late fall, after the leaves have dropped. Use commercial limesulphur, 1 part to 8 parts of water. Miscible oils are also effective. There are a number of brands of the miscible oils that give excellent results, however, the lime-sulphur also has a fungicidal effect, and, for this reason, is generally used in preference to the miscible oils. Remember that the whole tree must be thoroughly covered with the spray solution. Effective spraying for the San Jose Scale cannot be made while the foliage is on the trees; however, in bad cases, spraying with Whale Oil Soap, 1 pound to 6 gallons of water, in the spring (about May or June) when the young insects hatch, will help to hold them in check.

Other Scale-Insects. There are a number of other scale insects, such as Oyster-Shell Scale, Scrufy Scale, etc.

The Oyster-Shell Scale is about oneeighth of an inch long and resembles an oyster-shell in shape; it does not reproduce rapidly and thus control is not difficult.

Scurfy Scale is snowy white or dirty gray in color.

Both of these insects live orer the winter in shape of eggs which hatch in the early sr ring.

Control-If the dormant spray of commercial lime-sulphur is applied just before the leaf buds open, for control of the San Jose Scale, it has, also, been found to be effective against the Scurfy and Oyster-Shell Scales. However, where these scales are present in large numbers, spray when the young minute yellowish-white insects hatch, which is about May, depending on the season and latitude. Use Kerosene Emulsion, 15\% strength, or Whale Oil Soap, 1 pound to 5 or 6 gallons of water. In well-caredfor orchards, systematically sprayed, these insects will give, very little trouble.

Woolly Aphis. There are two formsone appearing on the limbs and trunk of the tree and the other on the roots. These are small, reddish-brown plant lice which are covered with a mass of whitish cottony substance.

Control-For the form which appears above ground, spray with Kerosene Emulsion, $10 \%$ strength, or Tobacco Extracts. To kill the root form, remove dirt around each tree to a depth of 3 or 4 inches over a circle with a diameter of 3 or 4 feet. Then, soak the soil with Kerosene Emulsion, $15 \%$ strength, using at least 2 gallons per tree. Rake back the earth. Treatment for the root form should be made during the spring or summer when the tree is in a vigorous, growing condition. Cultivate trees constantly so that a strong growth will result, thus enabling the tree to withstand the attacks of the Aphis.

Apple Aphis. There are several species of plant lice which attack apple trees. They are small greenish or rosycolored insects which suck the juice from the foliage, usually feeding on under surface of the leaves, causing the foliage to curl up. The presence of these insects is indicated by ants which are always found associated with the plant lice. 
Control-Must be sprayed with a contact insecticide such as Whale Oil Soap, 1 pound to 6 gallons of water, Kerosene Emulsion, 10\% strength, or with Tobacco Extracts. (See page 55.) It is important to spray these insects before the leaves are curled as it is difficult to hit insects when they are protected by the curled leaves.

Curculio. For detailed description and control see under Plum Curculio. This insect also attacks apple, making a crescent-shaped cut which eventually deforms the fruit. Thorough tillage, during July and August, will kill many of these insects when they are in the pupal stage. Spraying with Arsenate of Lead is the only satisfactory method of controlling the Curculio. The first Codling Moth spray (just after the bloom falls) and the second spray (two or three weeks after the bloom falls) will also be effective in controlling Curculio. Thickets' of wild crab apples or Hawthorn, when near the orchard, should be destroyed. (See also Plum Curculio, page 47.)

Canker Worm. Two species occur, one in the spring, and one in the fall. These are small caterpillars about $3 / 4$ to 1 inch long, commonly known as Measuring Worm, color varying from yellow to dark brown and variously striped. Feed upon the leaves of apple and other orchard trees, also attack shade trees.

Control-This pest is worse in old, neglected orchards which are not cultirated. Thorough cultivation will destroy many of the insects, as a part of their life history is spent in the ground. Spraying with $A$ rsenate of Lead, 3 to 4 pounds to 50 gallons of water, will control caterpillars when they are young. $\Lambda$ lso, another effective method is to put bands of tanglefoot or some similar sticky substance, or cotton, around the trunk, which will prevent the wingless females from getting on the trees.

Bud Moth. These are small, brownish caterpillars $1 / 4$ to $1 / 2$ an inch long, which attack the young terminal leaf buds and blossoms. Where commercial lime-sulphur is used just before the buds open for San Jose Scale, Arsenate of Lead (2 pounds to 59 gallons) may be added to control Bud Moth. Spray again with Arsenate of Lead (2 pounds to 50 gallons) just before blossoms open. See general spray directions for spraying the apple, page 42 .

\section{Apple Maggot (Railroad Worm).}

Small white maggot about $1 / 4$ inch long, which makes brownish tunnels throughout the fruit, causing apple to fall to the ground. Summer and early fall apples are especially attacked by this insect.

Control-Pick up and destroy all windfall apples every three or four days. Plowing and cultivating will lessen the injury from. this insect. Hogs in the orchard, if the trees are not too small to be injured, will destroy the affected fruit. Where the trees are carefully sprayed twice with Arsenate of Lead for control of the Codling Moth, the poison will help destroy the Apple Maggot. In well cared for and carefully sprayed orchards, this insect does very little damage.

Tent Caterpillars. Large, hairy caterpillars, when full grown almost 2 inches long, dark in color, with a white stripe down its back. It weaves silken tents or webs on the branches or on crotches of the trees during spring and summer. On the twigs, egg masses are laid, which are about $3 / 4$ inch long, forming a grayish-brown knot-like band. 


\section{$\underline{\mathrm{Stark} O \mathrm{rch} \text { a rd a n } \mathrm{Spray} \text { B o o k }}$}

Control-Egg masses should be collected and burned in the winter, also burn the nests or webs in the trees during the summer. The spraying of foliage with Arsenate of Lead as described under Codling Moth will control tent caterpillars.

Other Leaf-Eating Insects. Such as Bag Worm Leaf Crumpler, Cigar Case Bearer, etc., can usually be controlled by the general spraying treatment advised for apple orchards. See page 42 .

Apple Tree Borers. There are two species-the round head and flat head borer. Trees affected with borers are found to have small round or oblong holes in the bark from which sawdust often sifts out. Also discoloration of the bark is an indication of the presence of the borer. The round head borer is yellowish-white with a dark head. It is cylindrical in shape and about $3 / 4$ to 1 inch long. Bores into the bark, making small round holes, and remains in tree almost three years. The injury is most severe in neglected orchards. The adult is a white-striped beetle about $3 / 4$ inch long.

The flat head borer is usually found from base of trunk up ta the limbs, preferring trees which have been weakened or diseased. Small, light yellow in color, a! out 1 inch long, with a broad, flat head. This borer remains in tree only about one year, making burrows just under the bark which cause discoloration.

Control-The main method of fighting the apple tree borers is to cut out with a sharp knife, or to use a pliable wire to shove down the burrow, thus killing them. All trees should be gone over at least twice a year and worms cut out-once in the spring before May, and again in the fall. If the burrows are not straight enough for the wire to be pushed in, cut part of the bark away with a knife.

Various methods for preventing the entrance of the borer have been used with fair amount of success. Wrapping the trunks with wire netting, wood veneer, heavy paper, etc., (for method of applying see under Rabbit Injury, page 62) will prevent the female from laying the eggs in the bark. 'Wrappers should be applied in the spring before May, and any wrappers which keep out the sun should be removed the latter part of the summer, about August 1st. This period covers the egg-laying stage of the adult insect. If allowed to remain on too long, the bark will become tender and subject to insec $\_$and disease injury. Also, mounding up of the earth at base of the trees will force the borer to lay its eggs higher on the trunk, thus making it easier to cut them out. Various repellent washes, such as a mixture of Whale Oil Soap and crude Carbolic Acid have been used, which prevent the laying of the egg. Before wrapping trees to prevent the entrance of borers, wash the trunk with $10 \%$ Kerosene Emulsion. If Aphis gets under the wrapper, spray with Kerosene Emulsion.

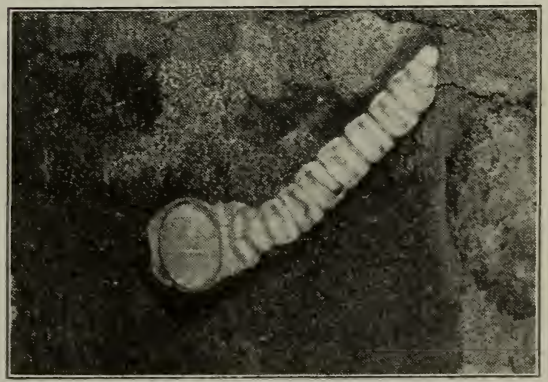

Flat-head Apple Tree Borer.

Cut out the borers every year, also note preventative measures under Apple Borers. 


\section{Stark Orchard a n d S p r a y B o o k}

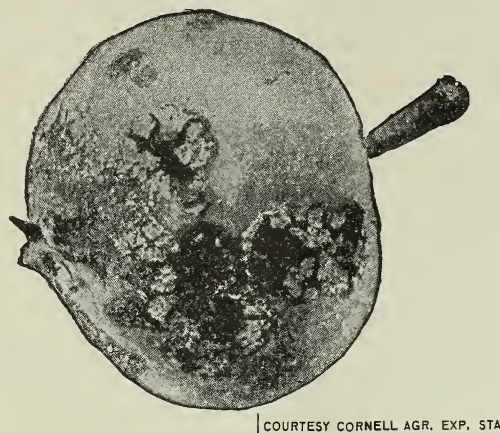

Apple Scab.

Injures the selling value of the fruit. One of the most common apple diseases.

One method found to be very effective in preventing entrance of the apple tree borers is to paint trees with pure White Lead mixed with raw Linseed Oil. The mixture should be about the consistency of thick house paint and should be applied once a year, in early spring, (May) and after the borers have been cut out. For protection against rabbits and mice it is advisable to paint the trees in the late fall. Make the trunk perfectly clean. Remove soil to a depth of 2 inches and apply the material thickly up as high as the limbs-filling every crack and crevice. It can be used on pome fruits (apple, pear, quince) for preventing entrance of the borer, and it will also be effective in preventing rabbit and mice injury. Caution: Use nothing but pure White Lead and pure Raw (not boiled) Linseed Oil. Do not use House Paint or any paint with a drier, as it will injure the trees.

"I have not had occasion to change my opinion concerning the use of pure white lead and raw linseed oil as a preventative of borers, mice and rabbits, but I would not wish to apply this material more than once per ycar, nor any thicker than ordinary house paint, nor to any trees cther than the pome (apple and pear) fruits."-H. A. Surface, Econemic Zoologist, Pennsylvania Department of Agriculture.

\section{Apple Diseases}

Apple Scab. Description-One of the most important apple diseases. Attacks fruit, leaves, and blossoms. Practically the same as pear scab. On leaves it causes small circular or oval spots, often making leaves fall prematurely. On the young fruit, it causes at first small, circular, dark spots which grow and form brown or black scabby spots, which cause fruit to crack open. If scab is very bad, it may cause dropping of a large portion of the young fruit. Scab is worse during wet, cool seasons.

The damage from apple scab is twofold-it injures the fruit so as to make it unfit for market, and also it destroys such a large portion of the leaf surface as to seriously reduce the vitality of the tree, so that it cannot properly ripen its crop or bear a good crop the following year.

Control-The best remedy is dilute commercial lime-sulphur (1 part to 40 parts of water with 2 pounds of Arsenate of Lead) or use Bordeaux Mixture (3-4-50) with Arsenate of Lead. First, spray just before blossom buds begin to open (when they show pink); second, spray just after the blossom petals fall, beginning when two-thirds of the blossoms have fallen; third, spray two weeks after petals fall. As far as possible, always spray just before rainsnot after.

Bordeaux Mixture was previously used exclusively for control of apple scab, but it causes what is known as Bordeaux injury, which appears as brown spots on leaves and russeting of fruit, even cracking the fruit in extreme cases. Sometimes Bordeaux injury is more injurious to the appearance of fruit than the scab. Never spray trees with Bordeaux Mixture during wet weather, On 


\section{Stark Orahard a n d Spra}

the other hand the dilute commercial lime-sulphur causes practically no injury when used in proper proportions and applied in a fine mist. Hence, dilute commercial lime-sulphur has practically displaced Bordeaux as a summer spray for apple and pear. However, lime-sulphur will not control Bitter Rot or Blotch. These diseases are controlled by spraying 8 or 9 weeks after blossoms fall with Bordeaux Mixture, which can be applied at this time without danger of injury to the fruit.

Bitter Rot. More common in the Southern States than elsewhere. On the fruit first in small pale brown specks which later become larger, darker in color and sunken, the margin remaining light colored. If the fruit remains on the tree, the fungus spreads all through it and makes it shrivel up into what is commonly known as a "mummy," which, if left on the tree all winter, will carry the fungus over until the following spring. On the limbs the disease appears as oblong, irregular, sunken cankers, covered with cracked bark.

Control-In winter cut off and burn cankers and pick off all mummied apples. To control Bitter Rot, spray eight weeks after the blossoms fall, using Bordeaux Mixture (4-5-50). Two weeks later spray again, using the same solution. In moist, damp seasons it may be necessary to spray a third time, two weeks later-same solution.

Blotch, Fly-Speck, Sooty Blotch and Fungus. Occur mostly in Southern States in moist localities.

The Blotch makes irregular dark spots on the fruit. On twigs, it causes a cankerous growth and on leaves small light brown spots.

Fly-Speck Fungus and Sooty Blotch cause small black dots on the fruit, looking like small piles of soot.

Control-Cut out all cankers on leares and twigs and paint wounds. These diseases are controlled by same Bordeaux Mixture sprays as used for the apple scab-(See general spray directions for the apple, page 42). The later Bitter Rot spray (8 weeks after the blossoms fall) will also be beneficial in preventing the spread of Apple Blotch.

Cedar Rust. Description - Yellowish orange spots on leaves and sometimes on fruit. Weakens the foliage and often causes falling of leares to considerable extent. The fungus lives during winter and early spring on red cedar trees and then spreads to apple foliage.

Control-Cut out nearby cedar trees, if practicable, also wild apple trees. Spraying is not entirely successful, but spraying for apple scab will control it to a large extent. Is not one of the most serious apple diseases.

Leaf Spot. Description-Several different kinds varying from tan to brown in color.

Control-The general outline for spraying apple, see page 42, will control this disease.

Canker. Description-There are several kinds and they are often confused with fire-blight, which is altogether a different type of disease. $\Lambda \mathrm{s}$ a rule, the Canker is rough and cracked, while in the case of the fire-blight the diseased portion is smooth. As a rule, Canker is usually found on old trees in orchards which have not been sprayed. The fungus that causes one of the Cankers also causes what is known as the Black Rot of the apple-resulting in the rotting of the fruit in storage or just before.it is picked. 


\section{S t a r k O r c hard a n d S p r a y B o o k}

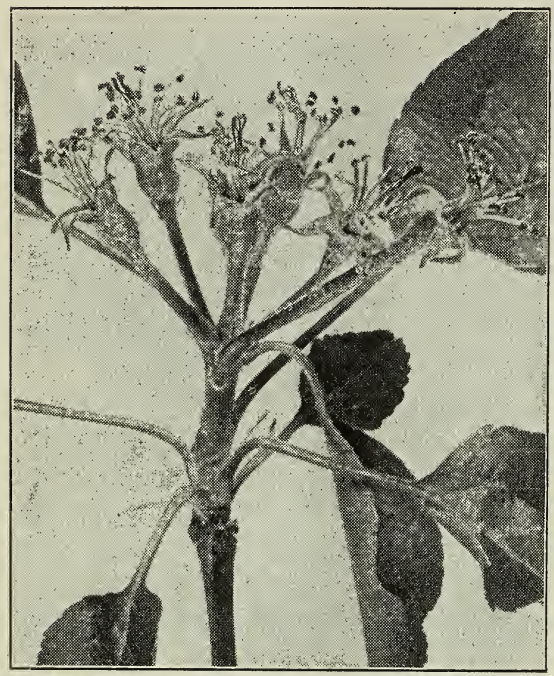

Just Right for Codling Moth Spray.

Calyx lobes are extended. Spray must be applied before blossom ends close.

Control-Cut out and burn all affected parts in he late winter or early spring and paint all wounds with pure white lead mixed with raw linseed oil. An application of concentrated commercial lime-sulphur, 1 part to 8 parts of water, or Bordeaux Mixture (10-10-50) in early spring, before leaf buds swell, will control the canker. In well sprayed, well cared for orchards, there is little trouble srom the Canker.

Fire Blight. For detailed description and control, see under pear, page 44. This is a bacterial disease and spraying will not control it. Diseased portions must be cut out and burned.

\section{Apple-General Treatment}

In the spring, before May 15, inspect the trees and cut out all borers. For full details see page 39 . Keep all the fire blight (twig blight) cut out at frequent intervals. See page 44 .
First Spray. Time. When tree is dormant, just before le: ? buds open in spring, spray with commercial lime-sulphur solution. (1 part to 8 parts of water, or with home-made concentrated lime-sulphur solution. See page 57.) This is for control of San Jose Scale and general clean-up of orchard.

Second Spray. Time. After leaf buds are open, but just as blossoms are beginning to show pink, use dilute commercial lime-sulphur solution (1 to 40) or Bordeaux Mixture (4-5-50); see page 57. Add 2 or 3 pounds of Arsenate of Lead paste. Spray before rain, not after. This spray controls $\Lambda$ pple Scab, and early leaf-eating insects like Canker Worm, Bud Moth, etc. In rainy seasons this spray is especially important.

Third Spray. Time. Just after blossoms fall, beginning when $2 / 3$ fallen. The most important application. Controls Codling Moth, Apple Scab, etc. Use dilute commercial lime-sulphur (1 to 40 ) or Bordeaux Mixture (3-4-50) and add 2 to 3 pounds Arsenate of Lead paste to 50 gallons of the spray solution. Spray thoroughly with highest pressure available-drive spray mixture downward and well into upturned blossom ends of young apples, so as to poison the larva (worm) of Codling Moth when it attempts to enter apple. Use a a nozzle which will produce a coarse, driving spray. See illustration above.

Fourth Spray. Time. Two or three weeks after Third Spray. Dilute commercial lime-sulphur (1 to 40) or Bordeaux Mixture (3-4-50) with Arsenate of Lead, 2 to 3 pounds to 50 gallons. Use a nozzle producing a fine mist for this, and all other summer applications except the one just after blossoms liave fallen. 


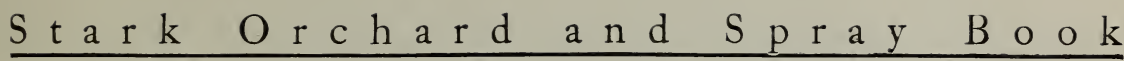

Where Bitter Rot must be controlled, spray eight or nine weeks after blossoms fall with Bordeaux Mixture (4-550 strength), also add 2 to $2 \frac{1}{2}$ pounds of Arsenate of Lead to 50 gallons of the solution to control the second brood of Codling Moth. In a warm, wet season, Bitter Rot is worse than in a dry season. An additional spray for Bitter Rot two or three weeks after the first Bitter Rot spray is advisable in wet seasons.

Whenever Aphis or other sucking insects appear when the foliage is on the trees, spray with $10 \%$ Kerosene Emulsion or with Tobacco Extracts, see page 55 or with Whale Oil Soap, 1 pound to 5 or 6 gallons of water.

\section{Pear}

The same insects attacking apple also attack the pear, such as San Jose Scale, Codling Moth, Curculio, Aphis, Borers, etc. Control is practically the same as in the case of apple, however, where dilute commercial lime-sulphur is used for summer spraying, it is advisable to use a weaker strength that is, 1 part to 50 parts of water for pear.

\section{Pear Insects}

\section{Pear Slug. Description - Attacks} pear, apple, cherry and sometimes plum. Small, slimy blackish worm about $1 / 2$ inch long; eats the green out of the leaves and skeletonizes them.

Control-Easy to control. Spraying with Arsenate of Lead, $2 \frac{1}{2}$ pounds to 50 gallons of water will kill the larvae. Fine air-slaked lime or almost any fine dust, if thoroughly dusted over the trees, will destroy a large percent of the Slug.

Pear Psylla. Description-Adult is small, winged insect about $1 / 10$ of an inch long, which lives over winter in crevices of the bark. They are closely related to plant lice and are sometimes called jumping plant lice; lay eggs in spring and the young appear early in the season. Young insect is minute, flat and yellowish, sucking the juice from the leaves and fruit. They secrete a honey dew in which a black mold grows, giving a sooty appearance which is good indication of the presence of Psylla.

Control-Adult insect lives over the winter in the rough bark of the tree. The roughened bark should be removed. The dormant spray with commercial lime-sulphur, (1 part to 8 parts of water) just before the leaves appear will destroy most of the eggs, also miscible oil sprays, if used when the tree is dormant, will kill many of the hibernating insects. If the dormant sprays have been neglected, trees should receive an application of Whale Oil Soap, 1 pound to 6 gallons of water, or Kerosene Emulsion $10 \%$ strength, or Tobacco Extracts. This application should be made just after the blossoms fall. If the later application is made, it should be made just after a rain which washes off the honey dew and allows the spray to hit the young insects.

Pear Leaf Blister Mite. Description -A minute mite which causes reddish blisters on the leaves, later turning black, often causing the foliage to drop.

Control-An application of commercial lime-sulphur ( 1 part to 8 parts of water) which should be applied while the tree is dormant, will control this insect. This is the same spraying as that for San Jose Scale-just before the ieaf buds open. Where the attack of this insect is serious, it will be necessary to make an additional spraying in the fall after the leares drop, using the same spray as noted above. 


\section{Pear Diseases}

Practically the same diseases that attack apple, also attack pear, such as Scab, Rust, Leaf-Spot, etc. The same methods that are used against the apple will apply to the pear.

Fire Blight. Description-Commonly called Pear Blight, also Blossom Blight, Twig Blight, Blight Canker, etc. It is worst on pear, but also attacks apple, quince, etc. A bacterial disease which causes dark brown or blackish, smooth cankers which hold over the disease during the winter. In the spring, during moist weather, whitish, sticky substance oozes out from the canker. This whitish substance is filled with bacteria. Insects feeding upon it carry the bacteria to the blossoms and young twigs. The infected blossoms and twigs turn brown and the leaves cling very tightly to the twig. These blighted twigs on the trees are a good symptom of the presence of this disease. The twig blighting is usually on old trees and if the disease is watched carefully and cut out, it need not become serious.

Control-Spraying will not control this disease. Remove all fruiting spurs on trunk or lower part of main branches because the blight may enter through the blossom and destroy the entire branch. Cut out all dead limbs and cankers with a saw or sharp knife. Be sure to cut well back to live wood several inches below the canker, so that all of the diseased portion will be removed. Wash the wounds with corrosive sublimate, 1 part to 1,000 parts of water. This strength solution can be made by dissolvinơ one tablet of corrosive sublimate (which can be purchased from your local drug store) in a pint of water. Keep your solution in a bottle or wood- en pail-marked "Poison." Solution can be applied to the wound with a sponge. Any large wounds should be painted with pure white lead mixed with raw linseed oil. Cornell Experiment Station authorities recommend the use of gas tar for painting the wounds. They report that it is an excellent preservative and has caused no injury. Cut off all blossom and twig blight, also remove water sprouts which are more susceptible to attack. Burn all diseased portions. Most convenient method is to have a sack to put your blighted twigs in and have a wooden bucket to hold the disinfectant solution which is not strong enough to burn the hands.

Most important point is to inspect the trees at least once a week during the growing season. In case of bad attacks, it is best to inspect every two or three days. Don't let the blight get started in your orchard.

\section{Pear-General Treatment}

Practically the same as general directions for spraying the apple, given on page 42 , except not necessary to make the last Bitter Rot sprays. For summer spraying of the pear the lime-sulphur should be 1 to 50 instead of 1 to 40 as for apple.

In the spring and again in fall, cut out the borers and treat the trees as directed on page 39. Pear Blight is one of the most serious of the pear diseases. Constant cutting out of the diseased portions is the only remedy. Cut out and burn all affected parts, and examine the tree carefully for the blight canker (black sunken dead portions in the bark) in the early spring, as these cankers spread infection to the twigs and blossoms of the pear. For detailed directions, see above, under Pear Blight. 


\section{$\underline{S t a r k O r c h a r d}$ a n d S pra y B o o k}

\section{Peach \\ Peach Insects}

San Jose Scale. On the young peach twigs and fruit the scale is surrounded by a pinkish color. For description see under Apple, page 36.

Control-Same as for apple, except that in case of a bad attack the trees should be headed in and forced to throw out new growth the following year. Burn all the prunings before spraying.

Curculio. For detailed description and control, see Plum Curculio, page 47.

Peach Aphis. Sereral species attack the peach which are similar in a general way to Aphis described under apple on page 37. These insects suck the juices of the plant.

Control-Same as for Apple Aphis, page 3i.

\section{Peach Tree Borer. Description-A} small, yellowish white worm about 1 inch long; causes gummy or jelly like substance to ooze from the base of tree.

Control-Dig out the worms with a sharp knife, using pliable wire to shove down the burrow, thus killing them. Dig out the borers not later than June 1st, wrapping the tree, if desired, as under Apple Tree Borer, page 39. This has been used with success by many orchardists. Also a thick whitewash, to be used instead of the wrappers, applied to the body of the tree will keep out some of the borers, although it is not as sure a method. Mound up the earth at the base of tree to a height of 1 to $1 \frac{1 / 2}{2}$ feet-this will make the insect lay its eggs higher on the trunk, hence it will be easier to cut them out. The earth should be mounded up before June 1st and in early fall should be leveled down. $\mathrm{By}$ constantly watching and cutting out the borers, they can be kept well under control. Go over your trees again in the fall and cut out the borers. Remove all gum from the wood and paint wounds with pure white lead mixed with raw linseed oil.

E. L. Morris of the University of California (Bulletin 228) advises use of Asphaltum for the peach tree borer. Quoted from Bulletin 228:

"Hard Asphaltum, grade C and D, was applied early in the sfring to partly infested trees. Asphaltum does not nenetrate, crack, deteriorate or bind the tree, since it yields to the slightest pressure. Four years of experimenting have not shown the least injury.

"Directions. In the fall throw the soil away from the trees and dig the borers. In the spring dig the borers again and apply a thick coat of Asphaltum. Material is applied warm with a biusl, 5 inches below to 5 inches above the ground. A thick, uniform covering is absolutely necessary for best results. It is easier to apply two or more coats than to try to put on more than will adhere permanently. First coat will harden quickly and the seccnd can be applied without loss of time."

Fruit Tree Bark Beetle. Description -A small brownish beetle about 1/10 of an inch long which makes small holes in the bark about the size of a pin-head. Diseased or weak trees are more often attacked by this insect. If the trees are kept in a healthy growing condition there will be little trouble from this beetle.

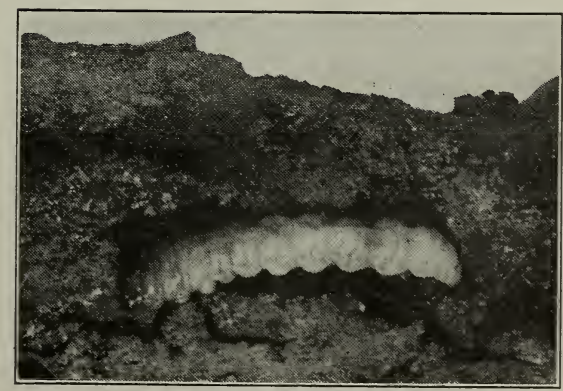

Peach Borer.

Causes the gummy substance at the base of peach trees. Cut out every year. 


\section{$\underline{\mathrm{Stark} O \mathrm{O} \text { c h a r d a n d S p r a y B o o k }}$}

Control-Remove all badly infected trees and limbs, burning all the prunings. Several applications of thick whitewash, one in early spring, one in midsummer and one in October will be helpful to healthy trees and prevent to a large degree the entrance of the Bark Beetle.

\section{Peach Diseases}

Brown Rot. This disease also attacks peach, plum and cherry and other stone fruits. Causes small brown spots on the fruit which enlarge until they rot the entire fruit; it then either drops or shrivels on the tree. Most serious in hot, wet weather, sometimes affects leaves, twigs and blossoms. Disease usually enters the fruit through the injuries made by insects, such as Curculio. Therefore, spraying with Arsenate of Lead to control the Curculio is most important. When the fruit hangs in clusters it is more subject to Brown Rot, which begins to decay where the fruits touch, hence peaches should be thinned so that no two peaches touch-not only to get larger size, but also to lessen attacks of the Brown Rot.

Control-Destroy all rotted peaches, also remove dried up "mummies" which remain on the tree. Spray with selfboiled lime-sulphur (8-8-50) with 2 pounds of Arsenate of Lead to 50 gallons of the solution. First, spray just as

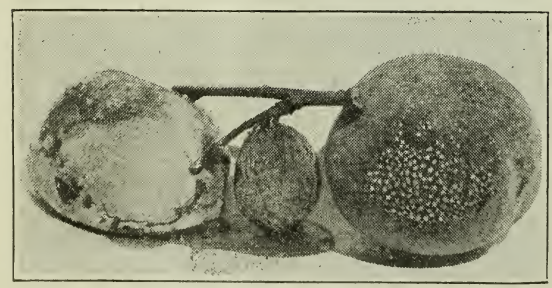

Brown Rot of Feach.

At right, specimen showing disease starting; left, rot far advanced; middle, a "mummy." shucks (calyces) are falling from the young fruit. Second, two or three weeks later, using self-boiled lime-sulphur 8-850 and Arsenate of Lead 2 pounds to 50 gallons of water. These two sprayings will, probably, be sufficient for early ripening varieties, but later ripening varieties should have an application about one month before fruit ripens, using selfboiled lime-sulphur 8-8-50, omitting Arsenate of Lead.

Peach Scab. Causes small black spots or freckles which at times become so serious as to cause fruit to crack open. This disease injures the selling quality of the fruit. Spraying for the Brown Rot will control this disease.

Peach Leaf Curl. This disease causes light green, yellowish or reddish wrinkled, swollen leaves which drop early; also attacks young twigs. The premature dropping of the leaves weakens the vitality of the tree. Spray with commercial lime-sulphur, 1 part to 15 parts of water, or Bordeaux Mixture (4-5-50 strength) applied just before the leaf buds begin to swell in the spring. If a careful, thorough application is made, this disease can be easily controlled. The spray for San Jose Scale, in the spring before the leaf buds swell, with commercial lime-sulphur ( 1 part to 8 parts of water) will also control Peach Leaf Curl.

Peach, Rosette, Little Peach, Etc, Science knows very little about these diseases which are related. Recognized by a sickly yellow foliage and clusters of weak shoots, also by premature ripening of the fruit and red streaks and spots in the flesh of the fruit.

Control-Dig out and burn all diseased trees as soon as discovered. 


\section{$\underline{\text { Stark Orchard and Spray B o ok }}$}

\section{Peach-General Treatment}

Dig out the borers in the spring before June 1st and again in the fall. See page $4 \check{\text { for details. }}$

Peach trees should never be sprayed with Bordeaux Mixture or commercial lime-sulphur when the foliage is on the trees. Self-boiled lime-sulphur which is merely a fine mechanical mixture of lime and sulphur, heated by slaking of the lime, will not injure the foliage of the peach. Arsenate of Lead is the only insecticide which should be used on the peach. If Arsenate of Lead is used alone, 3 or 4 pounds of good, fresh stone lime should be slaked and added to every 50 gallons of the spray solution. This will counteract any burning tendency that the Arsenate of Lead might have on the tender peach foliage. One of the trade solutions on the market, known as Atomic Sulphur, can be safely used for this and the following peach spraying for control of Brown Rot. Use 5 pounds of Atomic Sulphur to 50 gallons of water, adding 2 pounds of Arsenate of Lead.

First Spray. Time. During dormant season just before the leaf buds swell in early spring, use commercial lime-sulphur, 1 part to 8 parts of water. This will control San Jose Scale and Peach Leaf Curl.

Second Spray. Time. When calyces (shucks) have dropped from the young fruit, use self-boiled lime-sulphur, 8-850 and Arsenate of Lead 2 pounds to 50 gallons of water. This controls Brown Rot, Peach Scab, and Curculio.

Third Spray. Time. Two or three weeks after second spray, using same mixture as second spray.

Fourth Spray. Time. One month before fruit ripens use self-boiled lime-sulphur, 8-8-50 strength, for Brown Rot. Do not add Arsenate of Lead this time.

\section{Plum}

Enemies of the Plum are about the same as those of the Peach, such as San Jose Scale, Brown Rot, Curculio, Aphis, etc., and are controlled by same remedies.

\section{Plum Insects}

Plum Curculio. Attacks plum, peach, apple, quince, and pear. The Plum Curculio is a small, grayish-brown beetle, with characteristic hump on its back. On the fruit it makes a small, crescentshaped cut, under which it lays an egg. The egg hatches and the larva, which is the common white worm found in peaches, plum, etc., feeds on the fruit, causing it to drop. Becomes about $3 / 8$ of an inch long. Remains in the fruit about four weeks.

Control-Frequent cultivations in midsummer will destroy many of the insects. Also keep all rubbish cleaned up about the orchard as this furnishes hiding places for the insect. Gather all fallen fruit and destroy. Practice of jarring the trees is used by many orchardists. Rapping the trunk of tree with a padded mallet will cause many of the insects to drop. By means of specially constructed catchers made of canvass on wooden frames, the insects can be caught when they fall and then destroyed by hot water or kerosene. The jarring should be done in early morning. This

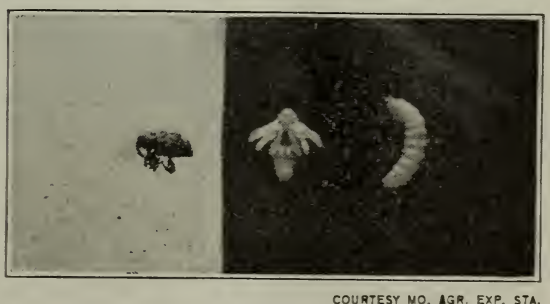

Curculio.

At left, adult beetle; middle, pupa; right, worm causing wormy peaches, plums, etc. 


\section{$\underline{\mathrm{Stark} O \mathrm{rch} \text { ard and Spray } \mathrm{B} \text { o o k }}$}

will help to control the Curculio, but the cnly sure method of control is spraying. First, spray with Arsenate of Lead (2 to 3 pounds to 50 gallons of water) just after the blossoms fall. Second, two weeks later, using same solution. This is the most important Curculio spray, and it should coat the fruit. General directions for spraying of plum (see below) will control the Curculio. If $\Lambda \mathrm{r}$ senate of Lead is used alone, use milk of lime which is made by mixing 3 or 4 pounds of fresh stone lime with a small amount of water, adding this to each 50 gallons of Arsenate of Lead solution. This will prevent burning of the foliage.

\section{Plum Diseases}

Black Knot. On the limbs appears as a black, swollen knot, sometimes several inches in length.

Control-Cut out and burn all affected parts in the fall. Watch the trees carefully and whenever this disease appears see that it is cut out immediately. In a well cared for and well sprayed orchard there will be little trouble from this disease.

\section{Plum-General Treatment}

Whenever Black Knot appears, cut it out, making the cut at least 4 inches back of the knot in order to get all the fungus.

Same directions as for spraying the peach. See page 47 .

Plums (except Japanese type) can also be sprayed with dilute Bordeaux Mixture, 2-4-50. The foliage of the Japanese plums is too tender for Bordeaux Mixture, therefore, use self-boiled lime-sulphur instead.

\section{Cherry \\ Cherry Insects}

Curculio. For detailed description and control, see under Plum, page 47.

San Jose Scale. For description and control, see under Apple, page 36.

Aphis. See under Apple, page 37.

Canker Worm. For description and control, see under $\Lambda$ pple, page 38.

Slug. For description and control see under Pear, page 43.

\section{Cherry Diseases}

Brown Rot. For description and control, see under Peach, page 46.

Leaf Spot or Shot Hole Disease. Reddish or brown spots on the foliage, causing leaves to fall prematurely. Diseased tissue of the leaf turns brown and often falls out, leaving a ragged, circular hole.

Control-Dilute commercial lime-sulphur (1 part to 40 parts of water). Spray just after shucks fall from young fruit. Second, two weeks later, using same solution, and third, after the fruit is picked, same solution.

Powdery Mildew. Young shoots and leaves covered with white patches, causing foliage to roll and drop early.

Control-Sprayings as outlined in the general spraying directions for the cherry will control this disease. Also spraying for Leaf Spot will control the Mildew.

\section{Cherry-General Treatment}

First Spray. When the tree is dormant, before the leaf-buds swell, use commercial lime-sulphur, 1 part to 8 parts of water.

Second Spray. As soon as calyx (or shuck) is off young fruit, spray with commercial lime-sulphur, 1 part to 40 parts of water, or Bordeaux Mixture, 
3-4-50 itrength, adding 2 pounds of Arsenate of Lead to 50 gallons. The foliage of sweet cherry is more tender than sour cherry, therefore, use self-boiled lime-sulphur, 8-8-50 (see page 58) on sweet cherry for this and following spray.

Third Spray. Two or three weeks later same material as second spray.

If aphis attack the foliage, spray as described under Aphis, page 37. The cherry slug skeletonizes the leaves. For control, see Pear Slug, page 43.

\section{Quince \\ Quince Insects}

Slug. For description and control, see under Pear.

Bud Moth. See under A pple, page 38.

Curculio. See under $\Lambda$ pple, page 38 .

\section{Quinces Diseases}

Black Rot. This is the same as Black Rot (Canker) of apple. On the fruit causes black spots to appear and a dry rotting of the flesh of the fruit, cankers on limbs.
Control-Cultivate orchard thoroughly. Cut out and burn all cankers. Spray thoroughly with Bordeaux Mixture (34-50 strength) just after the blossoms fall. Second spray, same solution two weeks lạter.

Rust. For description and control, see under Apple, page 41.

Blight. The same disease as the pear blight. See page 44 .

\section{Quince-General Treatment}

The insects and diseases of the Quince are very similar to those of the apple and pear, and the general outline for apple spraying can be followed for the quince.

\section{Grape}

All vineyards should be thoroughly cultivated. This will help to control many insects, and, if the vine is kept in a healthy, vigorous condition, it will be better able to resist attacks of insects and diseases.

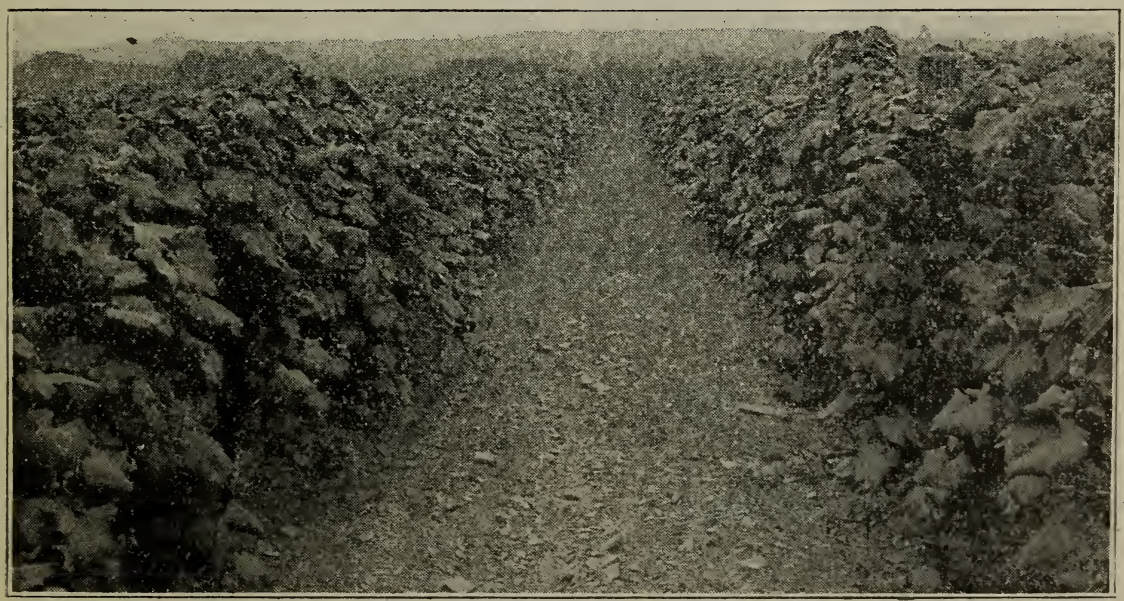

An Intensively Cultivated Vineyard in the Famous Lake Erie-Chautauçua Grape Belt. Here at Stark Bros. Grape Nurseries are pioduced the finest grape vines in the country. Thorough cultivation is an important factor in controlling erape pests. 


\section{Grape Insects}

Grape Root Worm. Small, white grubs (about $5 / 8$ inch long when fully matured) which live on the roots from September until June. The adult is a small grayish brown beetle (about $1 / 4$ inch long) which appears on the foliage about August-earlier in some sections -and eats peculiar chain-like holes in the leaves.

Control-Cultivate vineyard thoroughly in the early summer, which will kill many of the insects, also spray with Arsenate of Lead ( 3 or 4 pounds to 50 gallons of water, adding 1 gallon of Molasses). First, spray about latter part of June when the beetles are first noticed. Spraying must be done very thoroughly so as to coat foliage on upper and under side. When Molasses is added to Arsenate of Lead, it has the objection of lessening the sticking power of the Arsenate, but when necessary to use Arsenate of Lead and Molasses together it must be applied a couple of days in advance of a rain. Bordeaux Mixture will repel the beetle of the root worm, but, of course, will not kill the insect.

Grape Vine Flea Beetle. Small blue beetles about $1 / 5$ inch long, which attack opened buds in the spring, often eating entire bud. Eggs laid at the base of the buds where they hatch out brown grubs about $1 / 4$ inch long, which eat out irregular holes in the leaves.

Control-Spray with Arsenate of Lead (4 pounds to 50 gallons of water, adding 1 gallon of Molasses). First, in early spring, when buds begin to swell. Second, when grubs appear in May or June, spray with 2 pounds of Arsenate of Lead, 50 gallons of water and 1 gallon of Molasses. In well sprayed vine- yards very little trouble will be experienced from this insect.

Leaf Hopper. Small, active, yellowish insects about $1 / 8$ inch long, which suck the juice from the leaves, causing the leaves to become spotted, finally turning yellow and dropping to the ground.

Control-Clean up all fallen leaves and rubbish during winter, burn or plow it under in early spring.. Some growers have used sticky shields, made with canvas stretched over light wood frames, and sticky substance, such as tanglefoot, applied to the canvass. This will catch many of the adult hoppers. Spraying with Tobacco Extracts (see page 55) will kill many of the young insects. Whale Oil Soap ( 1 pound to 6 gallons of water) or Kerosene Emulsion $10 \%$ can be used, but the Tobacco Extracts are most effective. The Tobacco Extracts can be added to the Bordeaux Mixture and applied at the same time. Be sure to spray the under side of the leaves, thoroughly, as the insects are found there.

Rose Chafer (Rose Bug). Brown beetle, about $1 / 2$ inch in length, with long, spiny legs. Attacks the foliage and blossoms of many different plants.

Control-Spray with Arsenate of Lead (4 pounds to 50 gallons of water) and 1 gallon of Molasses, when insects first appear. These insects are hard to poison. When abundant, they can be handpicked or jarred into a canvas frame, then destroyed by kerosene.

Grape Berry Moth. Is the most common cause of wormy grapes. The worm, when full grown, is about $3 / 8$ inch long and dark in color. Feeds in the berry, often webbing several adjacent berries together. Worm cuts round holes in the 


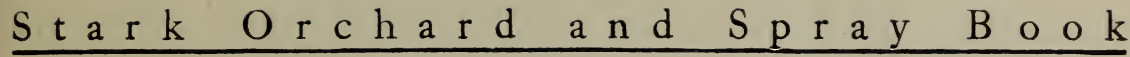

leaf, making a cocoon. Two broods every year.

Control-Pick off and destroy wormy berries about August. Plow under these in fall or spring. Spraying is the principal control. First, spray with Arsenate of Lead (3 pounds to 50 gallons of water) before the blossoms open. Second, spray after the blooms fall, same solution as for first spray, and third, spraying, early part of July, same solution.

\section{Grape Diseases}

Black Rot. The most serious disease of the grape. Causes reddish brown spots on the leaves. On the fruit, it starts as black or brown spots, but enlarging rapidly until the whole berry is rotted. The fruit shrivels and dries up into what is commonly known as a "mummy," which carries the disease over the winter and spreads the disease the following spring.

Control-The disease is worst during warm, rainy weather, hence in the rainy seasons more spraying will be necessary than during dry weather. Always spray just before a rain-not after. In the early spring, remove all mummied fruit from the vines and cultivate the vineyard thoroughly, plowing under all weeds, leaves and trash. Spray with Bordeaux Mixture, 3-4-50 strength. First, spray just the the third leaf is forming on new shoots. Second, just before bloom opens with Bordeaux Mixture, 34-50 strength, adding 2 or 3 pounds of Arsenate of Lead to control grape berry moth. Third, just after blooms have fallen, using Bordeaux Mixture and Arsenate of Lead, same strength as for the second spray. Fourth, 2 weeks laterBordeaux Mixture, 3-4-50 strength and Arsenate of Lead, 2 to 3 pounds. Fifth, two weeks later, spray with Bordeaux
Mixture, 3-4-50 strength, omitting the Arsenate of Lead. During wet seasons, other applications at 10-day intervals may be necessary, but do not use Bordeaux Mixture for the later spraying on account of staining the fruit. Instead, use Ammoniacal Copper Carbonate. See page 59 .

Downy Mildew. Grayish white mildew, which comes on both fruit and leaves. Spots on leaves are brownish on upper surface and covered with a white down on under surface, sometimes causing the affected leaf to fall. The fruit becomes soft and wrinkled, turning brown.

Control-The method of control is the same as Black Rot.

Anthracnose. Attacks leaves, fruit and young shoots. On the fruit is a dark brown spot with a reddish ring around it, hence often called Bird's-Eye Rot. On the leaves, spots are dark brown at first, having the darker margin; later, spots become grayish in color.

Control-Same as Black Rot.

\section{Grape-General Treatment}

All vineyards should be thoroughly cultivated. This will help to control many insects, and if the vine is kept in a healthy, vigorous condition it will be better able to resist attacks of insects and diseases. Early in the spring remove all mummied fruit from the vine

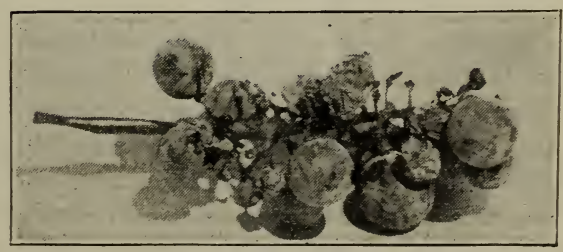

Black Rot of Grape.

The most serious grape disease, causes the berries to dry up and cling to the stem. 


\section{$\underline{\mathrm{Stark} O \mathrm{O} \text { chard a n d S p a y B o o k }}$}

and clean up all weeds and trash about the vineyard, either burning or plowing under. Bordeaux Mixture is the best grape spray for controlling diseases. Do not use lime-sulphur on grape vines. Ammoniacal Copper Carbonate is used for the late grape spraying, as it does not stain the fruit and is ef fective against late attacks of the Black Rot. See page 59 for method of making.

First Spray. Time. When third leaf is forming on the new shoot, use Bordeaux Mixture (3-4-50) and 2 or 3 pounds of Arsenate of Lead to 50 gallons of the solution.

Second Spray. Just before blooms open. Use same mixtures as for first spray.

Third Spray. Just after blooms have fallen, same materials as for first spray.

Fourth Spray. Two weeks later, same materials as first spray.

Fifth Spray. Two weeks after the 4th spray, using Bordeaux Mixture, 34-50 alone. Omit Arsenate of Lead.

In wet seasons later applications may be necessary, but for the late sprayings in order not to stain the maturing fruit, use Ammoniacal Copper Carbonate.

\section{Gooseberry}

Currant Worm. For description and control, see under Currant.

Mildew. A grayish white substance on the leaves which later becomes a dull brown. Also affects the fruit. Some of the English varieties are very susceptible to Mildew, but, as a rule, American varieties are relatively free from disease. In planting gooseberry, choose welldrained land where there is a good circulation of air.
Control-Spray with Bordeaux Mixture, 3-4-50 strength, or Potassium Sulphide, 1 ounce to 2 gallons of water, as the leaves begin to unfold. Several applications should be made at 10-day intervals until fruit is gathered. After the fruit is half grown, the Potassium Sulphide is more desirable than Bordeaux Mixture, as the latter stains the fruit.

\section{Currant}

Currant Worm. There are two species which feed upon the leaves of currant and gooseberry bushes. These worms are about $3 / 4$ or 1 inch long.

Control-First spray with Arsenate of Lead, 2 pounds to 50 gallons of water, just as the fruit is set. This can be applied at the same time as the Bordeaux Mixture. There is a second brood which can be controlled by Arsenate of Lead, 2 pounds to 50 gallons of water, after the fruit is picked. White Hellebore will also kill the worm and can be dusted on the plants early as soon as worm first appears. Hellebore can be purchased from your druggist, but be sure it is fresh.

Leaf Spot and Anthracnose. Several different diseases which cause the spotting of the leaves with a result that the foliage drops early.

Control-Spray with Bordeaux Mixture, 3-4-50 strength, which can be applied at the same time the Arsenate of Lead is applied to control Currant Worm.

\section{Raspberry}

Anthracnose. Circular or oval spots at first purplish, later becoming grayish with purplish border. Disease causes dwarfing of the canes and premature ripening and drying up of the fruit. 


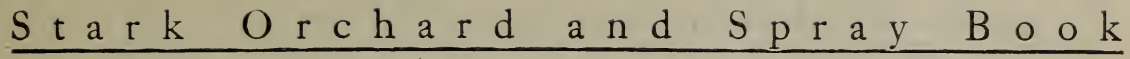

Control-Spray with Bordeaux Mixture, 3-4-50, when the new canes are 6 to 8 inches high in early spring. Second, two weeks later. When disease appears, cut out and burn diseased parts after picking.

Red Rust. See under Blackberry.

Cane Borer. A worm about 1 inch long, which bores into the cane, causing it to wilt.

Control-When the tips of the cane are seen to droop, cut them off well below the affected portion and burn all canes that have been attacked by this insect. Should be burned as soon as noted.

\section{Blackberry}

Anthracnose. See under Raspberry.

Orange Rust. Affects the leaves and young s'loots of blackberry and raspberry. On the under side of leaves are bright red or orange colored patches, which cause leaves to curl and become stunted.

Control-Cut out and burn all infected plants as the fungus winters in the roots.

\section{Shade Trees}

It is impossible to take up in detail in this small space, the various insects and diseases attacking shade trees, but in a general way the following will aid you in controlling these pests.

Any leaf-eating insect should be sprayed with $\Lambda$ rsenate of Lead, 2 to 4 pounds to 50 gallons of water. If sprayed on a plant with tender foliage (related to peach or plum), use 2 pounds of Arsenate of Lead and add 2 pounds of fresh stone lime.

Any sucking insect attacking the foliage of the tree, should be sprayed with
Kerosene Emulsion, 10\% strength, or, if spraying is done during dormant season (while leaves are off the trees), use commercial lime-sulphur, 1 part to 8 parts of water.

Some caterpillars, such as Canker Worm, may be kept out of a tree by banding the trunk with sticky material, cotton batting, etc. The nests of the Tent Caterpillar can be destroyed by burning out with a torch. The egg masses of many insects are found on the trees in the winter and these should be pruned off and burned.

\section{Roses}

Powdery Mildew. Grayish white substance on the foliage and young shoots.

Control-Spray with Potassium Sulphide, 1 ounce to $\mathbf{2}$ gallons of water, when leaves appear. Several other applicatiors should be made at 10-day intervals.

Rose Slug. A slimy snail-like insect that eats the leaves, leaving only the veined net-work of the leaf.

Control-Dust fresh Hellebore on the foliage at first appearance of the insect and at 10-day intervals until they disappear.

\section{Section II.}

In the following pages are included methods of making and applying the different spray mixtures.

When spray materials are purchased: be sure that you get them from a reliable firm. Our Special Service Department will gladly refer you to reliable companies. 


\section{Insecticides}

\section{For Biting or Chewing Insects}

Arsenate of Lead. The best poison for chewing insects. Adheres well to the leaves and when a good grade is used and applied in correct amounts, it does not injure the foliage. It is usually purchased in the form of stiff, white paste-containing about $50 \%$ water. Care should be taken that the paste does not dry out-keep surface of the paste covered with an inch or two of water. Arsenate of Lead can also be purchased in the form of a dry powder, and can be used with very ${ }^{\bullet}$ satisfactory results; however, in using the dry powder, as there is no water contained in it, you will need just one-half as much powder as paste.

In this book, wherever Arsenate of Lead is referred to and the amounts given, we refer to the paste form; hence, if you use the powder, you will need just one-half the amount mentioned.

In mixing the lead, measure out the desired amount, add a small amount of water and mix thoroughly; then pour into a barrel or tank and dilute to the desired strength. On peaches, do not use Arsenate of Lead stronger than 2 pounds to 50 gallons of water, and if Arsenate of Lead is not mixed with the self-boiled lime-sulphur, it is advisable to add 3 or 4 pounds of fresh stone lime to 50 gallons of the solution. This will tend to neutralize the burning tendency that the Arsenate of Lead might have.

Arsenate of Lead may be safely mixed with any of the lime-sulphur mixtures or with Bordeaux Mixture.

Hellebore. Its use is not practical on a large scale, as it is mort expensive than Arsenate of Lead. However, in the home garden it may be more convenient to use Hellebore for leaf-eating insects, such as Currant Worm. White Hellebore is a yellowish white powder, and can be applied full strength by dusting on the plant or diluted as follows: 1 pound of White Hellebore mixed with 5 pounds of flour or air-slaked lime. Exposure to the air will cause Hellebore to gradually lose strength. It acts as a stomach poison to insects, but it is harmless to man, in quantities recommended. This insecticide is used to some extent in small currant patches to control the Currant Worm.

\section{For Sucking Insects}

In using these contact insecticides, the spray must hit the insect in order to kill it, therefore, it is necessary to apply them with great thoroughness, both to the upper and under sides of the leaves.

Whale Oil Soap. 1 pound to 5 or 6 gallons of water, as advised. Cut up soap and dissolve in hot water, then add cold water (soft water) until desired strength is reached.

\section{Kerosene Emulsion.}

$\begin{array}{lll}\text { Hard Soap } & \ldots . . . . . . . . . . . . .1 / 2 & \text { Pound } \\ \text { Soft Water } & \ldots \ldots \ldots \ldots \ldots . . .1 & \text { Gallon } \\ \text { Kerosene Oil } & \ldots \ldots \ldots \ldots . . . .2 & \text { Gallons }\end{array}$

Cut up and dissolve soap in boiling water. Remove a safe distance from fire and while still hot, add kerose:re. Pump liquid back into itself with your spray pump until it becomes a creamy mass. This is your stock emulsion.

To make a $10 \%$ emulsion, add $\mathbf{1 7}$ gallons of water to 3 gallons stock emulsion. 
To make a $15 \%$ emulsion, add $10 \frac{1}{2}$ gallons of water to $\mathbf{3}$ gallons stock emulsion.

To make a $20 \%$ emulsion, add 7 gallons of water to 3 gallons of stock emulsion.

Tobacco Extracts. Can be made at home as follows: Tobacco Stems or Tobacco Dust, 1 pound; Water, 2 gallons.

Should be placed in hot water and brought to a boil. Keep the solution hot-not quite boiling-for one hour. The home-made solutions are not as satisfactory as commercial extracts. Two very satisfactory brands of the commercial tobacco extracts are the "Black Leaf Extract" and the "Black Leaf 40," which are manufactured by the Kentucky Tobacco Products Co., of Louisville, $\mathrm{Ky}$. Use as directed on the can. The "Black Leaf $40 "$ is $40 \%$ pure nicotine and is extremely concentrated. It is one of the very best sprays for controlling Aphis, Grape Leaf Hopper, etc. Use "Black Leaf 40 " at the rate of 1 gallon to 800 gallons of water. Dilute the "Black Leaf Extract" at the rate of 1 to 60 parts of water. When using the Tobacco Solution, an addition of 2 pounds of Whale Oil Soap to 50 gallons of the diluted solution will make it spread and stick better.

Miscible Oils. There are a number of different brands on the markte. These are used primarily for dormant sprays to control the San Jose Scale when the trees are dormant. They can be readily mixed with cold water and applied to the trees. "Scalecide" is a widely advertised mixture and if used properly, gives good results in controlling the San Jose Scale. If used, see directions for mixing, given by the manufacturer.
Commercial Lime-Sulphur. Is used at the strength of 1 part to 8 parts of water on the dormant trees (before the foliage appears in early spring) to control San Jose Scale. This same solution, when diluted 1 part to 40 parts of water, is a fungicide to control fungus diseases. For detailed description and methods of mixing, applying, etc., see below under Fungicides. A solution which corresponds exactly and is used in the same way as the commercial lime-sulphur can be home-manufactured. See directions under Fungicides, page 58.

\section{Fungicides}

Commercial Lime-Sulphur. This is a concentrated solution sold by the various chemical companies (a solution corresponding to the commercial limesulphur can be made at home; see page 58.) Commercial lime-sulphur is recommended by us when prepared by reliable companies. The value of these solutions depends upon their process of manufacture, which influences their degree of concentration. The more concentrated a solution is, the more water you can add to 1 gallon of the solution to get the desired strength. The concentration is determined by an instrument called the Beaume Hydrometer. Every grower who is going to use commercial lime-sulphur should have one of these instruments. It is simply a hollow glass tube with a weight in the bottom and a graduated scale of degrees marked on the side. The solution is tested by putting in the Hydrometer and reading the degree at the water level. A very satisfactory Beaume Hydrometer may be obtained at a cost 


\section{Stark Orchardand Spra}

of $\$ 1.00$ from the Bausch \& Lomb Optical Co., Rochester, New York, or you may order one through your local druggist. A solution that will test $\mathbf{3 3}$ degrees is fairly concentrated, while one that tests 26 degrees is rather dilute. Most of the commercial solutions test 30 to 33 degiees; they should not test lower than 30 degrees.

In the Concentrated Lime-Sulphur Solutions recommended in this little book, it is assumed that 32 degrees on the Beaume Scale is the Concentration of the Solution before Dilution for Spraying. If your Solution tests less or more than 32 degrees, refer to the Table given below for the Amount of Water to Add to One Gallon of Your Soiution.

Following table, computed by Mr. P. J. Parrott, of N. Y. Exp. Sta.

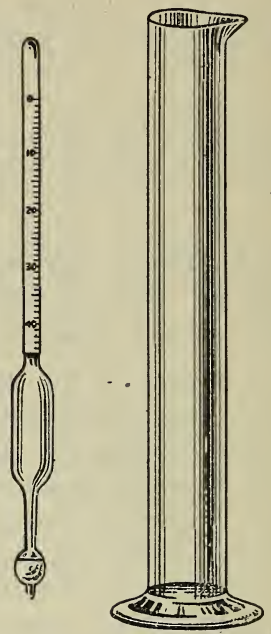

Hydrometer for Testing Lime-Sulphur.

Pour concentrated solution into container, read hydrometer, and refer to following table.

\section{DILUTIONS FOR DORMANT AND SUMMER SPRAYING WITH LIME- SULPHUR SOLU'IONS.}

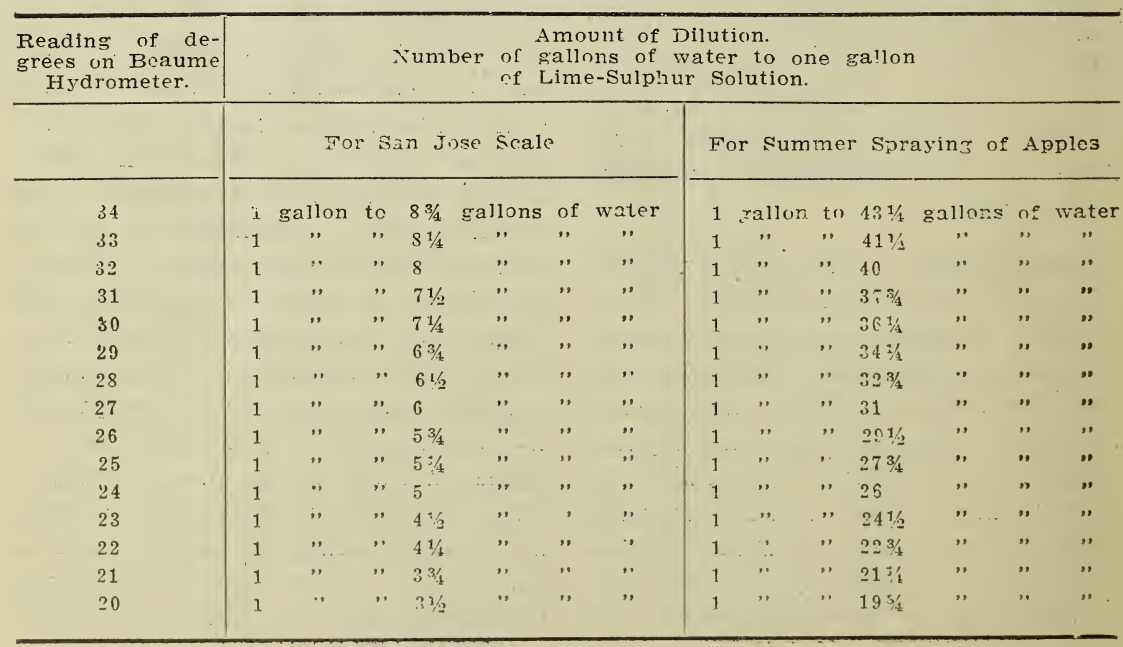


Home-Made Concentrated Lime-Sulphur. This corresponds exactly to the commercial lime-sulphur solutions, except that it will probably be somewhat less concentrated.

In general, it is advisable for the orchardist to buy his lime-sulphur solution from some reliable company instead of attempting to make it himself. However, if large amounts are required, it will probably be cheaper to make the solution on the farm. Only first-class materials should be used and extreme care should be taken in the process of manufacture.

The following formula for making home-made concentrated lime-sulphur is taken from Pennsylvania Bulletin 115 by Prof. J. P. Stewart:

50 lbs. Fresh Stone Lime (unslaked). 100 lbs. Sulphur, finely pulverized.

Water to make 50 to 60 gallons of total product at finish.

The lime should be relatively pure, at least $90 \%$ pure. Several forms of lime may be used, but it should be fresh. Do not use air-slaked lime. Sulphur should be finely ground-either "the flowers" or "the flour" of sulphur can be used.

Directions. Put 10 gallons of water in kettle and start fire. Place lime in kettle. After slaking is well started, add the dry sulphur to the lime or mix the sulphur with water enough to make a thin paste, which requires about 5 gallons. After slaking and mixing are completed, add water to make 50 gallons. Bring to a boil and stir until the sulphury scum practically disappears. Material should be kept well stirred, especially during early stages of the process. The time of boiling should be until the sulphur granules are evidently dissolved, generally 40 to 60 minutes. Pour or strain the clear liquid into a barrel or other storage ressel that can be completely filled and corked, or cut off air contact with a thin layer of paraffine or any heavy oil. This prevents formation of crystals.

Utensils for Making Lime-Sulphur Solution. Can use old iron kettles for boiling the solution over a fire. However, if large amounts are being made, it is much more satisfactory to boil by steam. If boiling by steam, proceed in the same manner as when boiling over a fire until the lime is slaked. Then apply live steam by running a hose into the mixture. Good distribution of the steam is essential. This is accomplished by admitting it at the bottom of the cooking vessel through fine holes and a good sized horizontal $\mathrm{T}$, with enough pressure to develop vigorous boiling. A single horse-power of steam is required for every 50 gallons of the solution to be boiled. By boiling with steam the mixture can be boiled in a barrel. In making lime-sulphur, a measuring stick is very convenient. This is made by planing down a good lath and then accurately marking on it the heights reached in the cooker by $6,8,10,15$, 20 , etc. gallons of water, making a notch at each figure. Strainers to keep out the coarse impurities and sediment should be used. The mesh of the strainer should be 30 to 50 to the inch.

Bordeaux Mixture. In the formula of Bordeaux Mixture, for instance 3-450 , the first figure (3) refers to 3 pounds of Copper Sulphate (Blue Stone); the second figure (4) refers to 4 pounds of Fresh Stone Lime, and the third figure (50) refers to $50 \mathrm{gal}$ lons of water. The more Copper Sulphate used (indicated by first fig- 
ure), the more concentrated is the solution.

Copper Sulphate (blue stone) 3 pounds

Lime (fresh stone lime, or hydrate lime) 4 pounds

Water 50 gallons

It is desirable to prepare stock solutions of the lime and copper sulphate.

Copper Sulphate (Blue Stone). Dissolve in water, allowing 1 pound copper sulphate to 1 gallon of water (for instance, in a 50-gallon barrel of water, dissolve 50 pounds of copper sulphate). To dissolve, suspend the copper sulphate in a sack near the top of the water. This will hasten the dissolving because the solution of copper sulphate is heavier than water and will sink to the bottom, thus bringing fresh water into contact with the copper sulphate.

This is your stock solution-to get one pound of copper sulphate, take one gallon of the stock solution.

Lime. Use fresh stone lime or hydrated lime. Do not use air-slaked lime. Slake the lime, applying water slowly at first, until it crumbles to a powder. When entirely slaked, add more water. Make stock solution by having 50 pounds of the lime mixed with 50 .gallons of water. Then you will have one pound of lime to every gallon of water. Do not allow stock solution to dry up. For fear the lime is not pure, use $10 \%$ more lime than the formula calls for, so as to be sure to have enough lime to neutralize the copper.

Making Bordeaux Mixture. To make 50 gallons of the 3-4-50 strength of Bordeaux, take 3 gallons of the stock solution of copper sulphate and pour into the spray tank. Add about 33 gallons of cold water. Then add 4 gallons of the stock solution of lime, and stir the mixture. Add enough water to make 50 gallons of the mixture.

Always dilute the copper sulphate as described, before adding lime.

The Ferro Cyanide Test. To make sure that you have added enough lime, you may test your solution as follows: Dissolve 1 ounce of Yellow Prussiate of Potash in a pint of water and label it "Poison." Add a drop of this solution to your Bordeaux Mixture, and if it turns brown you need more lime in the mixture. If it does not turn brown, your mixture is all right.

Never use Bordeaux Mixture which has stood over night-aiways make it fresh.

Self Boiling Lime-Sulphur. Can be used on peach and plum, as it does not burn the foliage. See general spraying directions for peach, page 47. This is not a boiled solution, as the name indicates -it is merely a mechanical mixture made by slaking the lime and adding sulphur during the slaking process, which results in a fine mechanical mixture.

Fresh Stone Lime (Quicklime) 8 pounds

Sulphur (flour or flowers of sulphur) 8 pounds

Water . .50 gallons

Put lime in a barrel, add a small quantity of water to start the slaking. Then make the sulphur into a paste by adding a small amount of water. Add this sulphur paste slowly to the slaking lime, which should be kept just covered with water-but not enough water to stop the slaking. Stir the slaking mixture constantly until the lime is all 


\section{Stark Orchard a n d Spray B o o k}

slaked. (This should take 5 to 15 minutes.) Just as quick as lime is all slaked, add enough cold water to make 50 gallons of the mixture. Strain it into the spraying tank (using a sieve of 20 meshes to the inch). While spraying, the mixture should be agitated constantly, as the sediment tends to sink to the bottom.

Arsenate of Lead ( 2 pounds to 50 gallons) may be added to mixture and it will increase the fungicidal value of the mixture as well as control the curculio and other chewing insects. This solution is used especially for the control of Brown Rot on the peach and plum.

\section{Ammoniacal Copper Carbonate.}

Copper Carbonate 5 ounces

Ammonia 3 pints

Water 50 gallons

Dilute the ammonia ( 3 pints) to 20 gallons of water. Make the copper carbonate into a paste, add it to the diluted ammonia and stir until dissolved. This mixture should be used soon after making as it loses strength on standing.

It is used as a late spray for the Black Rot of grapes in the place of the Bordeaux, as the Bordeaux would stain the maturing fruit. It is also used on other fruits when nearly ripe.

\section{Combination of Sprays}

Commercial Lime Sulphur can be mixed with Arsenate of Lead (for chewing insects) or with Tobacco Extract (for sucking insects). If necessary, all three of above materials can be mixed and applied at the same time.

A good combination of spray material for controlling sucking insects and leaf-eating insects is as follows: 5 pounds c: Whale Oil Soap (or any good soap), 1 gallon of Blac': Leaf Extract, $2 \frac{1}{2}$ pounds Arsenate of I eead and 50 gallons of water. If this solution is to be kept any time, add $1 \frac{1 / 2}{2}$ pounds of Lime.

\section{Spraying Machinery}

An efficient sprayer that will do the work thoroughly and in the least time, is the most desirable. Labor is a big item in the cost of spraying your orchard. Do not try to spray with small hand sprayers, because it is impossible to get sufficient pressure to thoroughly cover the tree with the spray. A barrel spray pump can be used if there are only a few trees. However, it is difficult to keep a high pressure in this small pump. For an orchard of five to ten acres, a spray tank mounted on a light wagon with a large double-acting horizontal pump, will be more satisfactory than the barrel sprayer. However, for orchards of ten acres or more, we advise the use of a good power sprayer. In a large orchard, for every twenty to thirty acres of bearing trees, there should be one power sprayer. The type of power sprayer depends largely on local conditions. If the orchard is hilly and rough, the spray rig should be light and built close to the ground. In fact, as a general proposition, all spray rigs should be fairly light.

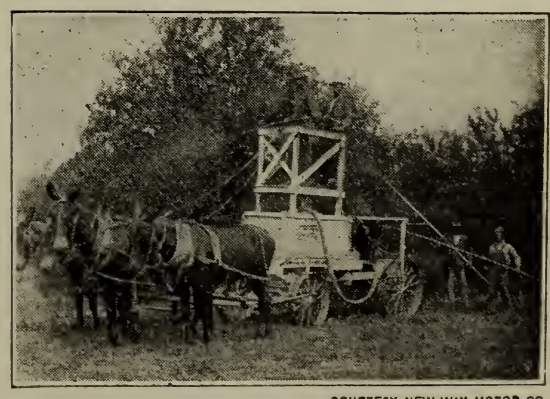

Power Sprayer.

Gasoline sprayers are best for large orchards. Note tower and leads of hose behind. 


Stark Orahard a n d S p ray B o o k

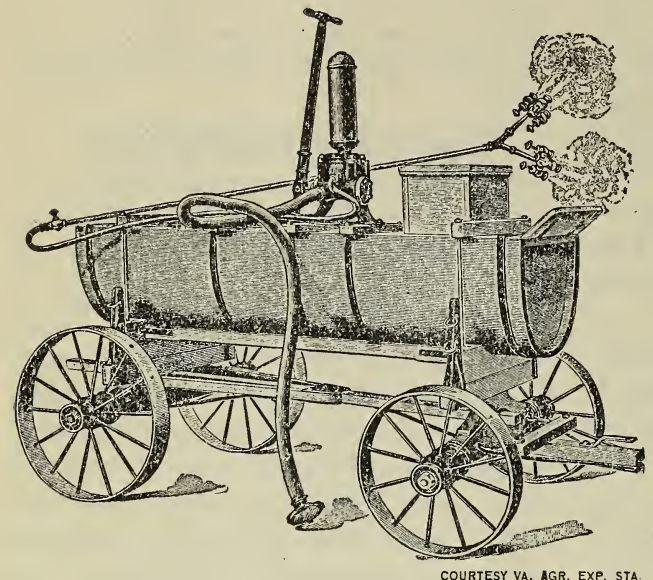

ICorizontal Hand Pump Sprayer.

An excellent type for small orchards-much mo:e satisfactory than a barrel pump.

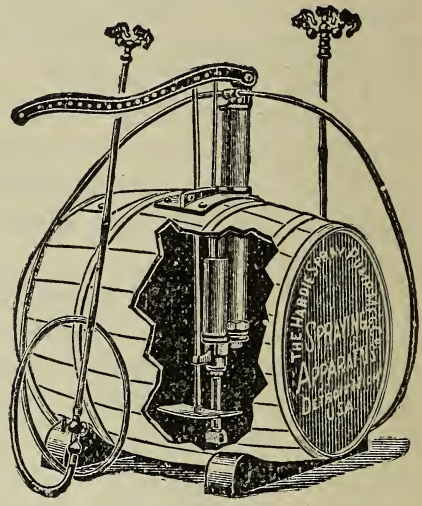

Barrel Pump.

All right for spraying a few trees-too small for an orchard.

\section{Essentials of a Good Spray Rig.}

Agitation. Be sure that provision is made for complete agitation of the spray solution. All spray mixtures, to obtain best results, should be kept constantly agitated, especially in the case of selfboiled lime-sulphur, being a fine mechanical mixture, agitation is absolutely necessary.

Engine. The construction of the engine should be simple. $\Lambda$ comp'ex engine generally means engine trouble.

Pressure. It is desirable io have high pressure, at least 150 pounds in power sprayers. Orchardists are just beginning to realize the importance of high pressure for spraying.

Traction Sprayers. In this type the pressure is maintained by a pump connected with a wheel of the truck and can be used for crops such as grapes, small fruits, etc., where the truck is kext constantly moving. In the case of large or- chard trees, there is not enough constant motion to keep up the pressure.

Pump: Where spray material, containing copper compounds (such as Bordeaux Mixture) is used, it is advisable to have all parts of the pump coming in contact with the solution to be of brass.

Use a strong spray hose, not less than 5-ply. Extension rod should be lightuse a bamboo rod lined with brass, especially for spraying from tower of power sprays. In spraying large orchard trees, it will be necessary to have the spray rig provided with a tower.

There are a number of good spray rigs on the market. Our Special Service Department will refer you to companies whose spray machinery has rroved satisfactory, and will also advise you as to the best syray rig for your particular needs.

In conclusion, buy your spray rig from a dependable concern and be sure that your rig is adapted to your particular use. 


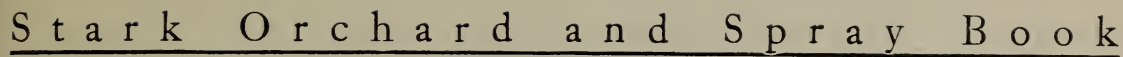

\section{Nozzles}

One of the most important points about spraying is to have a good nozzle. Some of the essential points of a good nozzle are as follows: it should not clog easily; should be easily cleansed; should be of simple construction and should not have any projecting parts to catch on the limbs.

For all sprays, except for the first Codling Moth spray (just after the blossoms have fallen), use one of the disc type nozzles, which produce a fine mist spray. See below. For the first Coddling Moth spray, where it is necessary to have a driving spray in order to force the poison into the open blossom end of the young apple, use a nozzle which will give this result.

The nozzle should be set at a 45 degree angle with the extension rod, thus making it possible to spray directly over the topmost branches and under the lower ones. Some of the nozzles are made with this 45-degree angle, or an elbow, giving the desired angle, can be used on the end of the rod.

Clusters of nozzles are often used, as it enables the grower to do the work more rapidly.

\section{Sun Scald}

"Importance of low headed trees cannot be too strongly emphasized. Hundreds of trees are dying ir all parts of the West because of the exposure of the long trunks to the afternoon sun, either directiy or by reflection. There is less injury from sun scald in the humid states.

"In addition to forming low heads, it pays to still further protect ihe trunks of newly planted trees from injury by sun scald. Various devices are vsed, such as wrapping the trunks with paper, wond reneer or by shading trunks on the southwest side by a thin piece of board set upright in the ground. Whitewashing the vung truriks to serve the same purpose has come to be extensively used in some sections. Whatever method is adopted, it should be employed soon after trees are planted and continued in sood condition to the seccnd winter or until the shade of the trees become ample."

Whitewash. Whitewash is much used in California to protect trees, both young and old, from injury by sun-scald.

"The California formula is as follows: Quicklime ............................ Tallow ............ 4 pounds. Salt .............. 5 pounds. Water enough to make mixture flow well.

"This makes a tenacious whitewash not easily washed off by rains or removed by other means."-Paddock \& Whipple, "Fruit Growing in Arid Regions."

\section{Mice and Rabbits}

Mice and rabbits often cause a great deal of damage by gnawing the bark of the young trees.

Mice rarely attack the trees unless there is rubbish, weeds or grass at the base of the trunk. Therefore, removing the rubbish and weeds will tend to prevent mice injury. Also mound up the soil to a heighth of 6 inches about the base of the tree. Protectors, such as wire netting or heary wrapping paper, etc., will also tend to prevent attacks of mice.

Rabbits are more difficult to control. By concentrated efforts of one locality, rabbits may be killed out to a large extent. There are also a number of protectors for the trees which are effective

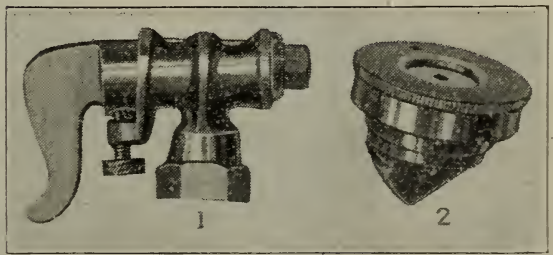

\section{Nozzles.}

1. Produces coarse, driving spray; used for codling moth spray, just after blossoms fall.

2. Produces fine mist, the best type of nozzle for all general spray work. L'sed for all spray, except the one just after blossoms fall. Note the angle of the neck. 


\section{S t a r k O r c hard a n d S p r a y B o o k}

against rabbits. Screens, made by using galvanized wire cloth of $1 / 4$-inch mesh, make an excellent protection against both mice and rabbits-24-inch width is convenient to use. By cutting into lengths of one foot or more, depending upon size of trees to be protected, the sections rolled on a round piece of wood so as to shape them into cylinders-in this way their own tension will close them completely around the tree, or they can be wired. Dig the dirt away from the base of the tree to a depth of several inches and then place the screen at the bottom of hole and fill it up with earth. Ordinary windor screen is very good to prevent rabbit and mice injury, and also prevents borers from laying their eggs in the trunk. It should be remembered that the egg-laying period of the borer is included from May 1st till August 1st, and any screens or wrappers should be on the trees during this period in order to prevent the adult insect from laying its eggs on the bark. Protective wrappers and screens to prevent rabbit injury should be applied in the late fall or early winter, and removed in early spring, just as soon as the snow is off the ground.

The Spiral Tree Protector is also very good for preventing rabbit injury. It is inexpensive and easy to handle. Wood veneer, paper protectors and building paper, etc., are also used, but as they exclude the sunlight from the trunk of the tree, often it results in making the bark tender and subject to sunscald if the wrappers are allowed to remain on during the summer. Any wrappers which exclude the sunlight should be removed in early spring. They also offer a place of concealment for insects, such as woolly aphis. All of the above protectors, except the spiral wire, also protect the trees from borers and mice.

Many orchardists have received good results from painting apple trees with White Lead mixed with pure raw Linseed Oil. This forms a covering which helps to prevent injury from apple tree borers, mice, and rabbits. For full directions of applying, see page 40 .

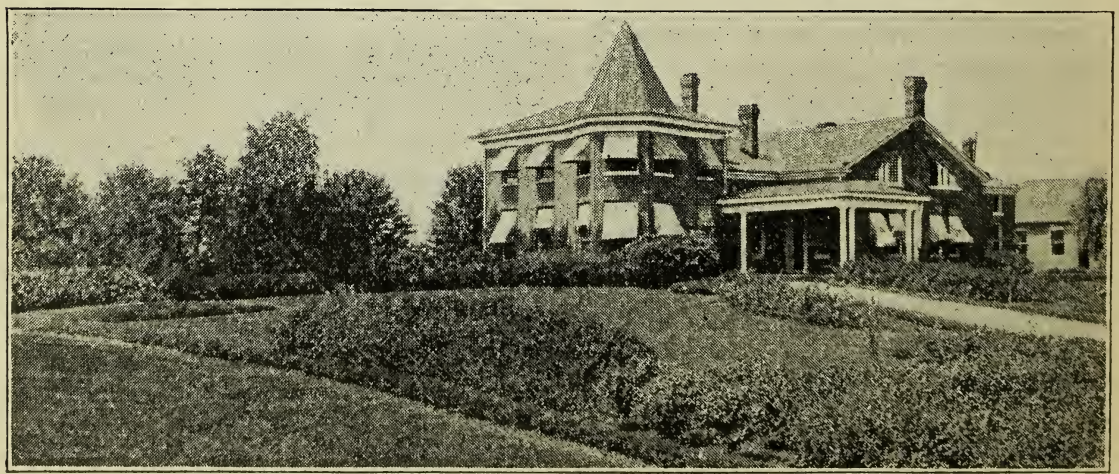

Office of Stark Bros. at Louisiana, Mo.

The largest institution of its kind in the world. In this office is located the headquarters of Stark Bros. Special Service Department. 


\section{Con}

In the foregoing pages, we have endeavored to give practical and up-to-date knowledge on important fruit-growing subjects.

We have quoted freely many of the leading horticultural authorities. Also much valuable data and information has been furnished by that great army, the Stark orchardists, men who have been taught by that greatest of all teacherspractical experience. We have endeavored to give all necessary information and we hope this beok will be of the source of increased orchard profits to you and the means of bettering orchard conditions throughout America. If, however, you desire any special information not thoroughly explained in this book, write without hesitation to our Special Service Department.

Our orchard experts stand ready to advise and assist you. This Service is furnished absolutely free and without oh! gation.

STARK BROS. NURSERIES \& ORCHARDS CO. Special Service Department

Louisiana, Missouri

All correspondence must be addressed to Stark Bros. Louisiana, Mo., not to our branch nurseries or individuals. 

. 


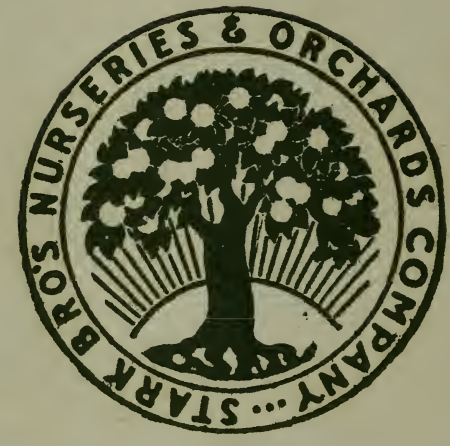

